Article

\title{
University Discourse to Foster Youth's Sustainability in Society amidst COVID19: International and Russian Features
}

\author{
Anastasia Atabekova \\ Law Institute, Foreign Languages Department, Peoples' Friendship University of Russia-RUDN University, \\ Moscow 117198, Russia; atabekova_aa@pfur.ru; Tel.: +7-966-121-8805
}

Received: 12 July 2020; Accepted: 2 September 2020; Published: 7 September 2020

check for updates

\begin{abstract}
This paper explores university discourse as a conceptual-communicative macrostructure that verbally represents international organizations' and universities' policies and activities to support youth's sustainable development to support youth's sustainable development amidst COVID19. The materials include universities' official site information and higher education-related data from international organizations regarding universities' activities during the pandemic. The textual corpus from 172 universities from Africa, Asia, Europe, North and Latin America, Oceania, as well as 164 documents with essential international institutional affiliations, were explored. The methodology combined qualitative and quantitative tools, theoretical, and empirical analysis. Data processing rested on thematic content analysis. Manual and computer-based coding techniques were applied. The analysis made it possible to identify major concepts and their constituents which form a verbally expressed conceptual macrostructure of university knowledge and action in fostering youth's sustainability during pandemics. The findings revealed some standard features within universities communication dimensions, on the one hand, and some specific to Russian universities on the other. Differences between universities and international organizations concerning communication focus were also identified. The research findings result in tentative recommendations to bridge Academia, University, and Society in efforts to foster youth's status and sustainability in contemporary civilization.
\end{abstract}

Keywords: education; sustainability; higher education; university; youth rights; communication; discourse; pandemics

\section{Introduction}

Youth is considered the human treasure and driving force for the development of civilization.

The UNO Agenda 2030 lays particular emphasis on the youth population in a number of its sustainable development goals (SDG), including health, education, and other issues.

As far as education is concerned, it is considered within SDG4, regarding the quality of education. Reference to higher education is found in several targets. Thus, target 4.3. declares the goal "by 2030 to ensure equal access for all women and men to affordable and quality technical, vocational and tertiary education, including university." [1]. Target 4.4. proclaims "the elimination of gender disparities and vulnerable population access to all levels of education". Among other targets of SDG4 the need for "productive learning environments, qualified teacher training, education for sustainable development and sustainable lifestyles, human rights, promotion of a culture of peace and non-violence" are mentioned [ibid]. As far as universities are concerned, they have been considered as a crucial tool for societal development across centuries [2]. Today higher education also plays an essential part of other goals related to poverty (SDG1); health and well-being (SDG3); gender equality (SDG5) governance; decent work and economic growth (SDG8); responsible consumption and production (SDG12); climate change (SDG13); and justice and strong institutions (SDG16) [ibid.]. 
However, currently, the sustainable development of global society is challenged by COVID 19 pandemic. It should be acknowledged that global health emergencies have shattered the world across centuries, including plagues, flus, AIDS, Zika, MERS, and COVID 19. Such diseases affect global society as a whole and lead to economic losses, political tensions, social constraints, which produces a negative impact on various sectors both at national and global levels [3]. Moreover, world-wide health emergencies result in the spread of disruptions which affect more specifically vulnerable populations, including youth [4].

Thus, it is logical that in line with past and present health emergencies researchers focused on the health communication crisis during SARS [5], on public governance issues during SARS [6], on students' stress, anxiety and psychological adjustment during SARS in different countries [7-9], and on media effects on students during the SARS outbreak [10]. Earlier scholars have also considered sanitary actions and health care management during H1N1 outbreaks in different countries [11,12], exploring students' perceptions of respective activities [13,14] and their mental status [15]. Researchers also investigated university staff and students' attitudes towards H1N1 pandemics in general $[16,17]$, and measures to ensure preventive health behavior in university settings during H1N1 [18,19]. Studies conducted in previous years concentrated on the tasks of universities providing consistent communication within the campus during emergencies [20], and also specified the need to engage youth in community emergency preparedness [21].

However, no explicit connection between the above disruptions and no focus on the concept of youth sustainability has been fostered so far.

This research follows the general vision of the concept of sustainability which scholars view "as a holistic concept ... whose challenge is to live in harmony, attending to environmental, social and economic variables, and to build a responsible and plural future over time" [22].

As far as youth sustainability is concerned, the latest research developments consider it as a multidimensional phenomenon that comprises young people's health, social inclusion and financial support, knowledge and education, international and national policies and governance, to foster tools for youth to obtain opportunities and benefits within the above-mentioned areas [23]. Therefore, it is logical that currently academia calls for studies that aim to identify stakeholders, their policies and actions that contribute to youth's sustainability, supported and fostered by universities amid the current COVID 19 pandemic [24]. Meanwhile, scholars agree that the university discourse on sustainability includes communication on various topics, including education and research, university governance [25], campus operations [26], and institutional digitalization [27], including sustainable management of higher education digital transformation [28]. However, researchers agree that the study of the university's role and potential in enhancing youth sustainability still lies ahead [29].

The present research hypothesis pursues a number of arguments:

(1) university discourse can play a comprehensive role in fostering youth sustainability in society in times of pandemic

(2) this comprehensive role is revealed through verbally expressed policies of universities and higher education-related organizations in relation to the topic under study

(3) university discourse on youth sustainability can be introduced as a verbally expressed conceptual-communicative macrostructure of knowledge and action.

The research goal is to check the above hypotheses and explore trends in international institutional and university discourse in relation to youth sustainability in society amidst COVID19 from the angle of discourse trends in verbal representation.

In line with the above hypotheses, goals and academic vision regarding university discourse on sustainability, the respective research tasks are as follows:

(1) exploring current trends in academic studies related to the research topic

(2) analyzing international universities' discourse across the world on youth issues amidst the current pandemic to identify verbally expressed concepts regarding policies and actions 
(3) investigating international organizations' discourse on university tasks amidst the current pandemic to identify verbally expressed concepts regarding policies and actions.

The key findings highlight the common and specific features of worldwide university communication during COVID 19, reveal some particular trends across major Russian universities, provide background understanding of international organizations' vision of such communication, and refer to preliminary recommendations on the verbally expressed conceptual macrostructure of university discourse to contribute to youth sustainability amidst the global pandemic.

\section{Materials and Methods}

\subsection{Research Methodology Framework}

The research rested on an integrated paradigm: combined qualitative and quantitative methodologies, theoretical and empirical analysis. The theoretical part followed the comparative approach to the investigation of academic papers that refer to the present research theme. The empirical part exploited a set of principles, approaches, theories, and techniques.

First, the principle of interdisciplinary studies of discourse [30] should be mentioned. It implies comprehensive analysis of linguistic data [31] with regard to cognitive-semantic macrostructures of communication that mirror some part of human reality [32], with a view of discourse as verbal representation of social semiotics [33] within a particular societal context [34].

Next, Minsky's [35] frame-based approach for representing knowledge was implemented. This theory served as the background to identify constituent items of concept formation through discourse production regarding youth sustainability.

Moreover, the research also exploited the theory of text complexity, expressed through conceptual density [36,37]. This theory helps to explore the complexity of cognitive processes and knowledge construction practices.

The analysis also used a grounded-theory approach. Scholars recommend this approach when no previous comprehensive data is available in line with the research theme [38]. In our case a grounded-theory approach was applied to consider field-based evidence and laid the grounds for further inductive reasoning.

The study also rested on the dispositive approach. This concept is used in line with Foucault's theory [39]. This approach allowed the author theoretical grounds for the study of the conceptual tree architecture of the discourse on youth sustainability.

The case study $[40,41]$ and corpus-based $[42,43]$ techniques were applied to structure the empirical data. Manual and computer-based thematic content analysis [44] were used for data processing.

\subsection{Data Collection}

The research focused on institutional communication within a digital environment which has become part and parcel of universities' and organizations' channels for internal and external communication [45].

The research data included two types of source.

The primary sources incorporated information from university official sites on university policies and activities related to COVID 19. The Quacquarelli Symonds (QS) ranking system site [46] was used for university selection (see Appendix A). Two universities with the top-ranking position from each country were subject to analysis. The order of countries appears in line with their ranking position in the data list. A total of 149 universities from all regions of the world (Africa, Asia, Europe, Latin America, North America, Oceania) were explored.

The list of universities that were subject to investigation, with links to their websites, is provided in Appendix A. Data related to COVID 19 issues with regard to students was relevant for the date of 31 May 2020. 23 Russian universities, including two of the oldest and most powerful national institutions and 21 members of the Russian nation-wide academic excellence project 5-100, were also 
considered. The list of Russian universities subject to investigation, with links to their websites, is provided in Appendix B.

Variables for the primary source data included the university's national origin, position in the ranking system, private/public status, and comprehensive/narrow-specialized nature. The textual corpus for university data reached 1,056,000 words, each university's textual data varying between eight-twelve items, with an average text size of 614 words.

Secondary sources included higher education related international institutional documents regarding universities' activities at the time of the 2020 pandemic. The data incorporated 164 documents from international and regional organizations, including UNO-affiliated agencies, the Council of Europe (CoE), the World Economic Forum (WEF), the World Bank, analytical data from internationally ranking corporations (QS and The Times Higher Education THE rankings), professional associations in the field of higher education, etc. In line with the research tasks, the Russian authorities' data on higher education during COVID 19 were also subject to analysis. The list of organizations and links to the websites/platforms from which sources were retrieved is introduced in Appendix C. Variables for the secondary sources data included organization status (international/regional), type of activities (comprehensive/specific field-focused), and genre of the textual data. The textual data for secondary sources corpus amounted to 239,112 words, each document's average size reaching 1458 words.

\subsection{Data Processing}

The textual data concerning each institution was first arranged as a separate case and then integrated into the university or international institutional discourse sample corpus.

Data processing including manual and computer-based coding techniques was applied.

The manual coding procedure was implemented by the author and three independent coders, who are Peoples' Friendship University of Russia (RUDN) university professors of English and deal with discourse and translation studies, with over 20 years' experience in research and teaching.

The coding process included predetermined and emergent codes [47]. The manually identified codes were subject to comparative analysis to reach inter-coder reliability among the above mentioned team of coding experts.

The second stage used the QDA Miner Lite tool (https://qda-miner-lite.software.informer.com/1.2/).

The analysis further included a computer-based automated search to identify the list of the most frequent word combinations and their affiliation with manually identified codes in the whole corpus.

In line with guidelines concerning required percentage in statistical research on language [48], only codes that reached $90 \%$ coincidence within the coders' data list and the computer-based list of most frequent word combinations were considered at the next stage of the study.

Further, the texts were organized into an electronic corpus for computer-based analysis through QDA Minor Lite. This tool was used to identify major concepts and their constituent slots within this structure and to consider their percentage use in the course of verbal discourse on youth sustainability.

\section{Results and Discussion}

This section provides data and its interpretation in line with the research hypothesis, goal and tasks. In line with the latter, this part includes three sections. Each one starts with the description of the obtained findings and moves to the discussion that considers them with respect to the tasks and hypothesis statements.

\subsection{Current Trends in Academic Studies}

This section introduces the empirical findings in line with research task one and discusses them with respect to research hypothesis statements one, two and three. 


\subsubsection{Findings}

The results of literature analysis reveal that COVID 19 has triggered academic research on the issues related to the challenges that youth faces amid the pandemic.

Academia explores various dimensions of the phenomenon. Some papers explore the impact of the pandemic on national educational systems, including the experience of particular countries [49].

The research tends to outline multidimensional activities of universities during the pandemic. Thus, scholars report that during the pandemic outbreak in their country university alumni engaged in raising resources and arranging medical supplies, scientists focused on emergency research, teachers had to enhance and refresh ICT based teaching tools and tactics, and university specialists also took an active part in providing psychological support services for local communities affected by the pandemic [50].

The study of literature makes it possible to say that scholars pay consistent attention to particular examples of university governance planning during the current pandemic.

Thus, Regehr and Goel [51] consider the stages of university management at various stages of health emergency in regard to COVID 19, including key stakeholders, measures, and target audiences at pre-planning, approaching crisis, immediate crisis, prolonged uncertainty, and recovery stages. It seems important that researchers use concrete university examples of COVID-19 related policies and guidelines [52].

Scholars also explore diverse university community attitudes to knowledge dissemination and disease prevention policies and practices [53], and analyze these activities from the angle of their influence on youth confidence in the context of their national government policy as a whole [54]. In line with the above, researchers argue for the urgent need to systematize and target communication with youth during the pandemic [55], to foster the call for youth inclusion "in matters that affect their lives" [56], and to underline the importance of "youth leadership in rebuilding a sustainable world in the post-COVID 19 period" [57]. With respect to this issue scientists further highlight the relevance of providing culturally responsive and sustaining youth participatory activities during COVID-19 [58]. Studies from different countries confirm the rise in patriotic feelings among youth who engage in social volunteering and support for vulnerable populations during COVID 19 [59].

Scholars also consider economic consequences that might affect young lives due to the potential unemployment rise in the post-COVID 19 period [60]. Moreover, researchers predict changes in the philosophy and policy of education in various countries [61], prospects of higher education internationalization in the student community, and autoethnography being revisited [62]. Topics relating to the specific requirements and tools for unscheduled digital pedagogy also draw specialists' consistent attention [63]. Within this area of academic studies current papers argue for particular instruments for unscheduled on-line teaching and explore perspectives thereof in different countries, including, for instance, China [64], Georgia [65], and Ghana [66].

Academia also focuses on students' feedback concerning unscheduled online learning [67] and lays emphasis on the mental, psychological, and physical condition of the young generation. Scholars acknowledge that COVID 19 affects youth's mental health $[68,69]$ and changes the psychological conditions of students and staff [70-72]. Further, specialists warn about the negative consequences of physical inactivity and sedentary behaviour in youth due to quarantine measures [73], and even say that there might be a potential generation lost in terms of sports activities [74].

Some papers focus on specific youth audiences. Researchers reveal challenges that incarcerated youth face in solitary confinement during COVID 19 [75,76]. There are also increasing voices on violence and abuses of youth during the pandemic [77] and these explore school measures to prevent these challenges [78].

The latest publications also relate some of the above mentioned areas of higher education institutions' activities during COVID 19 specifically to foster universities' internal and external communications, in order to contribute to sustainability in society amid the pandemic [79].

The above brief description of findings from research papers about COVID 19's impact on university policies, activities, and challenges that the student population faced leads to the following discussion. 


\subsubsection{Discussion}

The results of the literature review reveal that academia strives to respond to the burning issues related to university and institutional support for youth within the pandemic landscape. However, the current analysis concerns particular countries. Researchers have not moved to an international dimension yet. To our mind, this is due to the initial stage of the research within a particular period of time. Country specific data needs to be accumulated first. Therefore, a cross-country study of university communication on youth issues during COVID 19 seems timely as it helps us to consider the situation through the lens of international practice to identify global trends. Additionally, such a world-based perspective would continue academia's long-standing tradition of viewing the university's capacity to contribute to sustainable social development across the centuries $[80,81]$

Moreover, the above-mentioned papers focus on specific issues (i.e., social, educational, and health) with no explicit reference to the idea of the comprehensive role which universities can play during pandemics with respect to youth's sustainability. Meanwhile, there is an academic tradition of considering the role which university activities and communication can implement within the global agenda on sustainable development $[82,83]$. Thus, an explicit message on the need to explore and foster the comprehensive role of the university in supporting the community in general and youth in particular during COVID 19 seems timely and productive within the framework of the UNO Agenda 2030 on sustainable development.

The study of existing research findings shows that they distance themselves from themes related to verbal representation of policies that universities and higher education-related organizations conduct in relation to the topic under study. Current papers focus on students' perceptions and university measures themselves and omit the consideration of their conceptual representation through the means of linguistic discourse. The review of the literature confirms that academia does not on the whole view university discourse on youth during pandemics from the angle of a linguistically "shaped" conceptual macrostructure of university knowledge and action to foster sustainability among this population in times of health emergencies. These themes have not been subject to research with reference to official communication from international higher education related organizations. Meanwhile, interdisciplinary discourse studies confirm that language bears a strong power within society [84], and influences human minds, policies and actions [85], underlining that particular structural categories can play a critical role in communication as a tool and guide for action [86]. Thus, there is a contradiction between the discourse studies tradition in general, on the one hand, and current research on university communication during pandemics, on the other.

The above deliberations contribute to the need to explore university discourse verbal units from the angle of their capacity to foster youth's sustainability during health emergencies.

\subsection{International Universities Discourse across the World on Youth Amidst the Current Pandemic}

This part of the paper introduces findings with regard to research task two that requires the identification of verbally expressed concepts relating to the respective institutions' policies and actions. The findings are represented in two sections. Section 3.2.1 integrates data on major conceptual and structural features of university communication related to COVID 19 across the international landscape, including some specifics relating to specific universities across the world. Section 3.2.2 provides particular comments with respect to leading Russian universities. The discussion of empirical results is introduced in Section 3.2.3 in line with the research hypothesis statements one, two, and three.

\subsubsection{Common and Specific Features of University Discourse across the International Landscape}

The general profile of the universities whose discourses' conceptual-communicative structure was subject to study is introduced in Table 1. This lists institutions with regard to regions, countries and number of sources. The data shows that the analysis covered four universities from two African countries, 56 universities from 28 countries in Asia, 23 universities from 12 countries in Latin America, 
four universities from two countries in North America, and four universities from two countries in Oceania. The references and links to the websites of the particular universities are introduced in Appendix A (universities across the globe) and Appendix B (Russian universities).

Table 1. General profile of primary source data with regard to regions, countries and number of universities.

\begin{tabular}{|c|c|c|}
\hline $\begin{array}{l}\text { Region, } \mathrm{N} \text { of Countries } \\
\text { Present in the } \\
\text { Quacquarelli Symonds } \\
\text { (QS) Ranking Data }\end{array}$ & Country & $\begin{array}{l}\text { Total Number } \\
\text { of Universities }\end{array}$ \\
\hline Africa, 2 & South Africa, Egypt & 4 \\
\hline Asia, 28 & $\begin{array}{c}\text { Singapore, China (Mainland), Hong Kong SAR, Japan, } \\
\text { South Korea, Malaysia, Taiwan, Saudi Arabia, Kazakhstan, } \\
\text { India, Israel, United Arab Emirates, Lebanon, Qatar, } \\
\text { Indonesia, Brunei, Pakistan, Macao SAR, Oman, } \\
\text { Philippines, Turkey, Iran, Jordan, Bahrein, Kuwait, Iraq, } \\
\text { Bangladesh, Vietnam }\end{array}$ & 56 \\
\hline \multirow[t]{2}{*}{ Europe, 29} & $\begin{array}{l}\text { United Kingdom, Switzerland, Germany, France, } \\
\text { Netherlands, Belgium, Sweden, Ireland, Denmark, Finland, } \\
\text { Norway, Italy, Austria, Spain, Czech Republic, Estonia, } \\
\text { Belarus, Portugal, Lithuania, Greece, Hungary, Poland, } \\
\text { Bulgaria, Ukraine, Slovenia, Slovakia, Latvia, Romania, } \\
\text { Malta, Croatia. }\end{array}$ & 58 \\
\hline & Russian Universities & 23 \\
\hline Latin America, 12 & $\begin{array}{l}\text { Argentine, Mexico, Brazil, Chile, Colombia, Peru, Uruguay, } \\
\text { Cuba, Costa Rica, Ecuador, Venezuela, Panama }\end{array}$ & 23 \\
\hline North America, 2 & United States, Canada & 4 \\
\hline Oceania, 2 & Australia, New Zealand & 4 \\
\hline
\end{tabular}

The analysis focused on university website content. Each university's data were considered as a textual case. The content-based analysis revealed a set of thematic codes, which characterize specific university communication topics related to COVID 19 issues. Further, these universities' overall textual data were subject to computer-based processing that identified the most frequent language units and their affiliation with the thematic codes. The results of manual and computer-based coding and thematic content analysis made it possible to identify major concepts and constituent slots that characterize university youth-centered discourse, its aims, and its respective tools. The data is visualized in Figure 1.

Seven major concepts were specified within the phenomenon of international universities' communication within the COVID 19 pandemic (dark blue boxes), whose presence on the university websites reaches at least $50 \%$. The concepts consist of particular constituent slots (light green boxes). Currently, 31 slots are present in communication practices of either every or most (over $50 \%$ of data) universities from the list under study.

In addition, 12 specific items have been found with regard to particular universities. These items are united under the concept of 'University promising practices'. They do not reach $50 \%$ presence in the textual data under study. However, it seems relevant to take them into account as examples of positive experience.

Analysis reveals that the list of these slots varies with respect to a particular university. The most consistent list of such slots refers to the concepts of Information provision, Education, and Campus facilities operations. Communication on the issues related to support for the human being, student inclusion in society activities to stop the virus spread, and financial support shows a lower percentage of concept constituent slot distribution frequency. However, the absolute figures of some slots within the mentioned concepts are higher, as the figure reveals. 


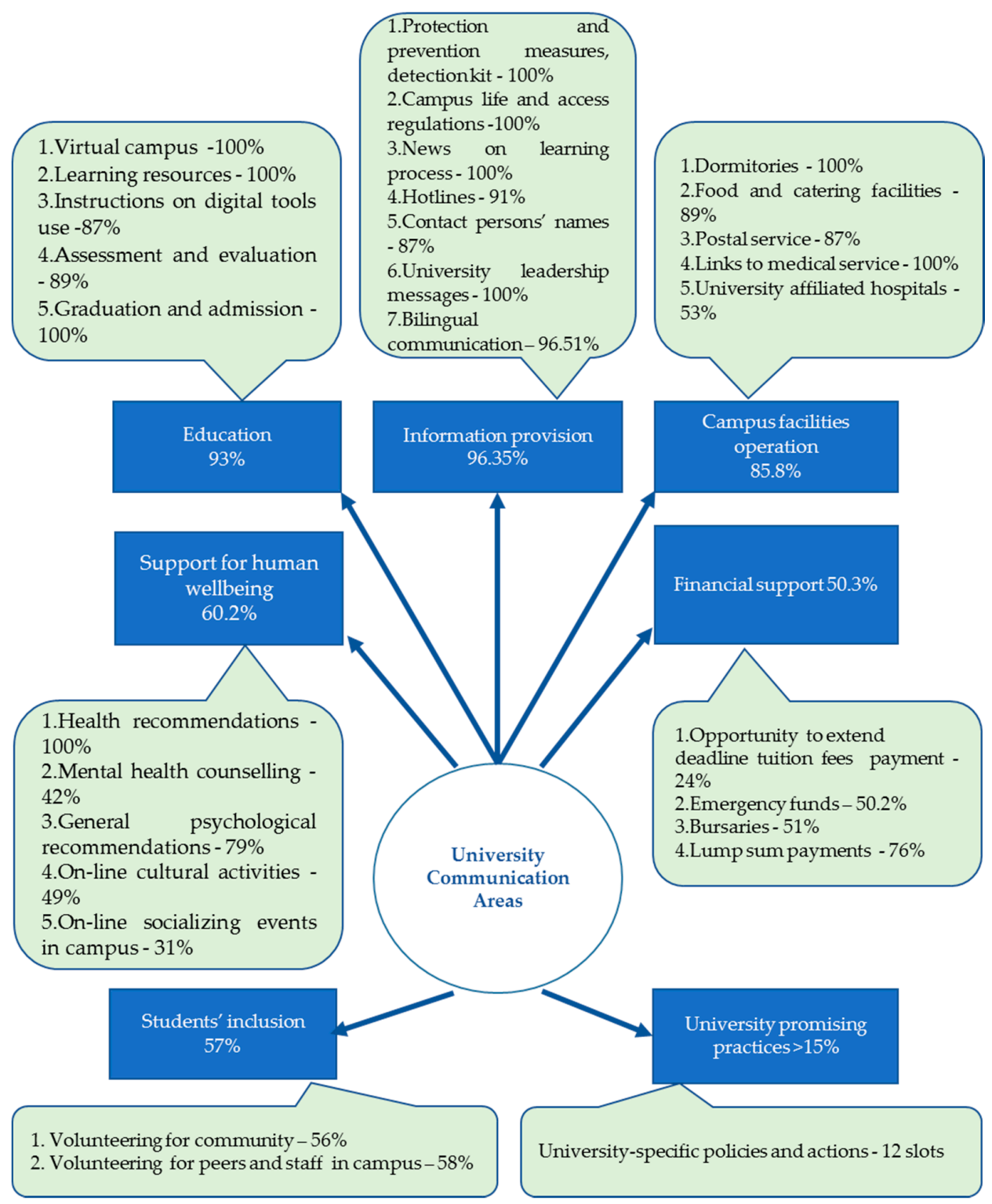

Figure 1. Concepts and their slots within the phenomenon of universities communication within the COVID-19 pandemic. (Author's data).

The slot Bilingual Communication within the Information provision concept deserves particular comment. Most universities in countries whose state language is not English provide information in English. This seems to mitigate information provision tension in terms of foreign students' access to information in case they have not mastered the local language.

The University promising practices concept also requires a specific consideration. We have distinguished this concept as a conventional one due to the fact that the analysis revealed specific topics of a particular university's communication. The examples of such topics are as follows, and the respective slots were:

(1) Self-quarantine is a civic duty (Kuwait University, Kuwait)

(2) University as an institution which, in cooperation with industry, produces a systemic input into society's fight against the pandemic, including plasma donation, ventilator supplies, patient treatments, data analysis, vaccine development (Universidade de São Paulo, Brazil)

(3) Tuition exemption for students affected by COVID-19 epidemic (Kyoto University, Japan) 
(4) Measures and principles for preparing an individual continuity plan for remote learning (École polytechnique fédérale de Lausanne, Switzerland)

(5) Device borrowing service (The University of Sydney, Australia)

(6) Opportunities for on-line internship (Sapienza University, Italy)

(7) Graduate support on the job market, on-line fairs for graduates' job placement (McGill University, Canada; Tsinghua University, China; Tomsk State University, Russia)

(8) Issues related to sexual assault, sexual health, and consent (The University of Sydney, Australia)

(9) Cyber-security (Tecnológico de Monterrey, Mexico)

(10) Multifaith chaplaincy (The University of Sydney, Australia)

(11) Students' stories from campus during COVID 19 (USA, UK, France, Spain, Latin America Universities, Russian universities)

(12) Students' polls (University of Cambridge, Russian Universities)

Details can be found on universities' websites (see Appendices A and B).

The list reveals that the themes aim to balance learning issues in line with students' societal inclusion (items 1 and 2), their individual situations, capacities, and needs (items 3-5). Other specifics specify the need to provide further career support (items 6-7), to ensure social wellbeing and security (items 8-9), to contribute to cultural identity support (item 10), and to focus specifically on students' experiences and voices (items 11-12).

The data did not allow the study to identify significant variables related to the university affiliation to a particular region or country, to its position in the QS ranking system, and to an institution's private/public status.

As far as the verbal means are concerned, Figure 1 shows that the major concepts are verbally expressed through nominative phrases organized from nouns and adjectives, and prepositions might appear as well. Syntactical density does not go beyond a three-member phrasal structure. At the level of the concept slots, a more specific structure also takes place. Along with verbal design, which is similar to that of the major concepts, some slots have a more dense syntactical structure (more items in the nominative line). Verbal nouns and adjectives reach $12.5 \%$ in the concepts and their slot structure.

\subsubsection{Particular Comments with Respect to Discourse in Russian Universities}

Compared with international communication practice, communication in Russian universities mirrors the same trends and percentage of activities related to education, information provision, campus facilities operation, and health service contacts. Students inclusion is limited to volunteering in the university and outside community, though this shows a comparable percentage of these activities mentioned in communication. Similar figures are revealed with regard to communication on human wellbeing, though the topics are limited to psychological recommendations and on-line cultural activities, and no comprehensive approach to mental health issues is found.

Nonetheless, it seems timely to underline that other configurations of selected universities, both foreign and Russian, might change the percentage landscape. Moreover, the comparative approach to the analysis has made it possible to highlight a number of features with respect to Russian universities' discourse on their operation during COVID 19; these remarks are based on the official federal documents related to higher education institutions (HEIs) and Russian universities' data on their websites. These features derive from the explicit nation-wide mandatory administrative-legislative regulation of university community activities by the Federal Ministry of Science and Higher Education. Further, we provide a number of particular comments to support the above statement with concrete examples.

Each university which was subject to study published on its web-site federal legislation and respective internal regulations (uploaded on each university site) that standardize the procedure and requirements for the education process, the faculty and student body's activities, mid-term and final assessment, and admission procedure during the current pandemic. The COVID 19 sites of the universities' platforms that were explored are linked to the Legislation section. 
Second, it should be mentioned that the Russian Ministry of Science and Education took a consistent lead in guiding and monitoring the overall situation, as well as in making it public. The official YouTube channel of the Russian Federation Ministry of Science and Education streamlined and published video conferences during the lockdown period (from 16 March to 16 June) of the Russia-wide sessions under the Ministry's umbrella. They were held with the mandatory engagement of all HEIs to monitor and coordinate activities and support students and staff [87]. The universities' digital platforms provide a link to the ongoing information from the Ministry in their COVID 19 News section.

Further, under the Ministry's recommendation each university (and even faculty, in case of a major federal university) has set forth a situation task force as a university/faculty-wide provisional division. This incorporated Vice-Rectors and heads of key departments. The unit had to foster and speed up inter-departmental communication and activities coordination, including education process administration, student and staff health condition monitoring and medical service provision in case of need, university infrastructure control, etc. [88]. The university platforms that were explored are linked to the page Situation task force division.

Under the Federal Ministry recommendations, the leading Russian universities supported other Russian universities across the country, sharing their digital educational resources with the overall Russian higher education institutions [89]. The COVID 19 sites of the university platforms that were explored are linked to the page Shared open access educational resources.

Similar to international universities' practices, a particular emphasis was laid on students' financial support during COVID 19. The Russian Federation Ministry of Education issued the order on student bursaries [90]. In line with this order, universities announced students' right to lump-sum financial support through the universities' contingency and labor unions funds. The information from Peter the Great Saint Petersburg Polytechnic University can be used as an example [91]. The COVID 19 sites of the university platforms contain a link to the page Ministry order on bursaries and information about university activities to implement it.

Further, the Ministry of Science and Education has initiated a program of support for students' job placement [92]. The relevant recommendation was also made public on the university sites. Some universities provided concrete facts about the ways they used to put the idea into practice by recruiting students for university staff positions related to technical support for the digitalized education process, design of digital sources, etc. [93].

It also seems essential to mention that Russian university websites (73\%) consistently publish students' stories from the campus and even transmit these stories to the mass media and TV [94]. The respective data contributes to the downplaying of panic downplaying and the fostering of social confidence.

Another common trend in the Russian higher education landscape refers to students' surveys. The Russia-wide service for public surveys conducted student surveys during the pandemic with regard to the quality of education during the lockdown period. $53 \%$ of students consider the quality of distance learning to be high, and $32 \%$ of respondents simply rate it as normal. Only $12 \%$ of university students complained about the low level of teaching during this period, sociologists say [95]. Universities themselves also launched student polls on their difficulties and the level of their satisfaction with the services provided. By 31 May 202019 out of 23 Russian universities under study had launched the respective surveys. The examples can be found on university websites [96,97]. Moreover, the analysis of Russian university websites reveals that the institutions tried to meet the language needs of international students. The data on health, education, campus services, social activities, and engagement in volunteering and research is provided in English, as well as Russian; moreover, some universities which lead in international student recruitment provide up-to-date communication in other foreign languages, for instance in Chinese, Spanish, and Portuguese, as can be revealed on the site of the Ural Federal State University [98].

On the other hand, the earlier mentioned sources [88] also confirm that the Russian government has acknowledged that the quarantine period became a stress-test for national digital educational 
platforms for higher education. The Russian Federal Minister of Science and Education specifically underlined insufficient technological capacity, acknowledged lack of open massive open online courses (MOOC) in university disciplines that are mandatory under federal state educational standards, and mentioned specific challenges to the learning process at technical, medical, and engineering faculties/institutions in terms of internships and lab-based research-led activities.

The above description of our findings from manual and digital content analysis of concepts that universities consistently verbalize in their communication on youth issues during COVID 19 leads to the following deliberations.

\subsubsection{Discussion}

The empirical data introduces university discourse on youth issues during COVID 19 as a system of verbally represented concepts and their constituent slots. This system thematically covers diverse areas of university activity related to youth support during COVID19. The concepts nominate the areas of university policies and activities and the slots name the tools for their implementation. Thus, it is possible to state that university discourse to support youth during COVID 19 operates as a cognitive communicative macrostructure. As this macrostructure integrates heterogeneous concepts and slots, it has a cognitive-communicative multidimensional nature which stems from different tasks (management, logistics, education, sanitation, social, communicational, etc.) that universities have to solve for the sake of youth sustainability support during COVID 19. Moreover, the slots that form the system of concepts verbally represent those tools that an institution uses to solve these tasks. Therefore, the conceptual communicative macrostructure of university discourse introduces university policies as a comprehensive system of tasks and tools to solve them. Consequently, the identification of the multidimensional macrostructure reveals the essence of the comprehensive role of university discourse in fostering youth sustainability in society in times of pandemic. Thus, the empirical data of Section 3.2 support research hypothesis statement 1 on the comprehensive nature of the university role in fostering youth sustainability during the current pandemic.

The next point in this discussion refers to research hypothesis statement 2. This underlines the role of verbal tools in the representation of the above-mentioned university comprehensive role. The empirical study has made it possible to compile a list of those verbal units that the university discourse uses to verbalize its policies in order to foster youth sustainability during COVID 19. The results show that the university discourse across the world uses a quite standard system of language units in terms of their meaning (described earlier in the section) and grammar forms (nominative phrases, limited number of items in the phrases).

Furthermore, the findings show that the macrostructure under study includes concepts of universal significance and concepts related to university's specific values, verbally introduced through the respective language units. Thus, this research supports the idea of Zwaan [99] about generally accepted and context-dependent concepts with regard to the same subjects, and tailors the generalized idea of Van Dijk [32] on global structures in discourse, interaction and cognition to a new emerging area of communication, namely university discourse on youth issues during the current pandemic. The concepts identified in the course of the empirical analysis correlate with the conceptual background of the definition of youth sustainability, provided in the Introduction section. Therefore, the findings described in Sections 3.2.1 and 3.2.2 support research hypothesis statement three that university discourse on youth sustainability can be introduced as a verbally expressed conceptual macrostructure of knowledge and action.

\subsection{International Institutional Discourse on Universities' Tasks amidst the Current Pandemic}

This part of the paper provides findings with regard to research task three and aims to identify the verbally expressed concepts of international organizations' policies and actions. The empirical study revealed some common features and topics of particular focus within discursive the conceptual-communicative macrostructure of various institutions. Therefore, these findings are 
introduced in Sections 3.3.1 and 3.3.2. The results are further discussed in Section 3.3.3 in line with research hypothesis statements one, two, and three.

\subsubsection{Common Features}

The data on international organizations' discourse on the university's role during COVID 19 become a secondary source as international stakeholders provide recommendations and can even monitor their implementation. In line with variables mentioned in the description of Materials, the analysis of secondary source data took into account major genres. The sources, including their institutional affiliation, types of genre, and respective number of analyzed documents, are introduced in Table 2.

Table 2. General profile of secondary source data with regard to the type of organization and documents issued. (Author's data).

\begin{tabular}{|c|c|c|}
\hline Organization/Institution & Type (Genre) of Documents & $\begin{array}{l}\text { Number of } \\
\text { Documents }\end{array}$ \\
\hline \multirow{3}{*}{$\begin{array}{c}\text { UNO and agencies under its umbrella } \\
\text { UN secretary general office } \\
\text { UNESCO } \\
\text { United Nations Office on Drugs } \\
\text { and Crime }\end{array}$} & Position/policy papers/statements & 3 \\
\hline & Analytical papers & 31 \\
\hline & Guidelines and recommendation & 7 \\
\hline $\begin{array}{l}\text { and Crime } \\
\text { United Nations Population Fund, } \\
\text { The SDG-Education } 2030 \text { Steering } \\
\text { Committee }\end{array}$ & $\begin{array}{l}\text { Applied resources } \\
\text { (platform) }\end{array}$ & 2 \\
\hline International Labor organization & Analytical Papers & 2 \\
\hline World Health Organization, & Analytical Papers & 3 \\
\hline World Economic Forum & Analytical Papers & 16 \\
\hline \multirow{2}{*}{ World Bank } & Position/policy paper & 1 \\
\hline & Updating resource list of platforms & 1 \\
\hline \multirow{2}{*}{$\begin{array}{c}\text { The Compact for Young People in } \\
\text { Humanitarian Action }\end{array}$} & Position Paper & 1 \\
\hline & Guidelines & 4 \\
\hline \multirow[t]{2}{*}{$\begin{array}{c}\text { International Association of } \\
\text { Universities }\end{array}$} & $\begin{array}{l}\text { Compilation of resources from other } \\
\text { international, regional and national sources } \\
\text { (recommendations, monitoring, distance } \\
\text { learning support, calls and webinars) }\end{array}$ & $\begin{array}{l}38 \text { by the date } \\
\text { of } 31 \text { May } 2020 *\end{array}$ \\
\hline & Survey & 1 \\
\hline \multirow{2}{*}{ QS World University Rankings } & Analytical reports & 13 \\
\hline & Surveys & 3 \\
\hline $\begin{array}{c}\text { Times Higher Education World } \\
\text { University Ranking }\end{array}$ & Analytical reports & 21 \\
\hline \multirow{5}{*}{ Council of Europe } & Position/policy papers/statements & 4 \\
\hline & Official Briefs & 4 \\
\hline & Analytical Papers & 5 \\
\hline & Interviews & 4 \\
\hline & Applied Modules for Resources & 3 \\
\hline \multirow{2}{*}{ The European Students' Union (ESU) } & Position Paper & 1 \\
\hline & Analytical reports & 7 \\
\hline \multirow{2}{*}{$\begin{array}{c}\text { European Association for } \\
\text { International Education (EAIE) }\end{array}$} & Guidelines and recommendations & 2 \\
\hline & Survey & 1 \\
\hline \multirow{3}{*}{ EDUCAUSE } & Analytical data & 7 \\
\hline & Recommendations & 12 \\
\hline & Learning resource platform & 5 \\
\hline
\end{tabular}

Note: * 38 sources and links for active by the date of 31 May 2020. 
The thematic content analysis of the data highlights several trends. First, international organizations consistently engage in rapid response to COVID 19 through policy statements, analytical reports, surveys and interviews, applied tools, and solutions, to ensure the continuity and quality of education in general and that of university-based training in particular.

The study of the respective documents and tools makes it possible to specify major concepts and their constituent slots, introduced in Figure 2.

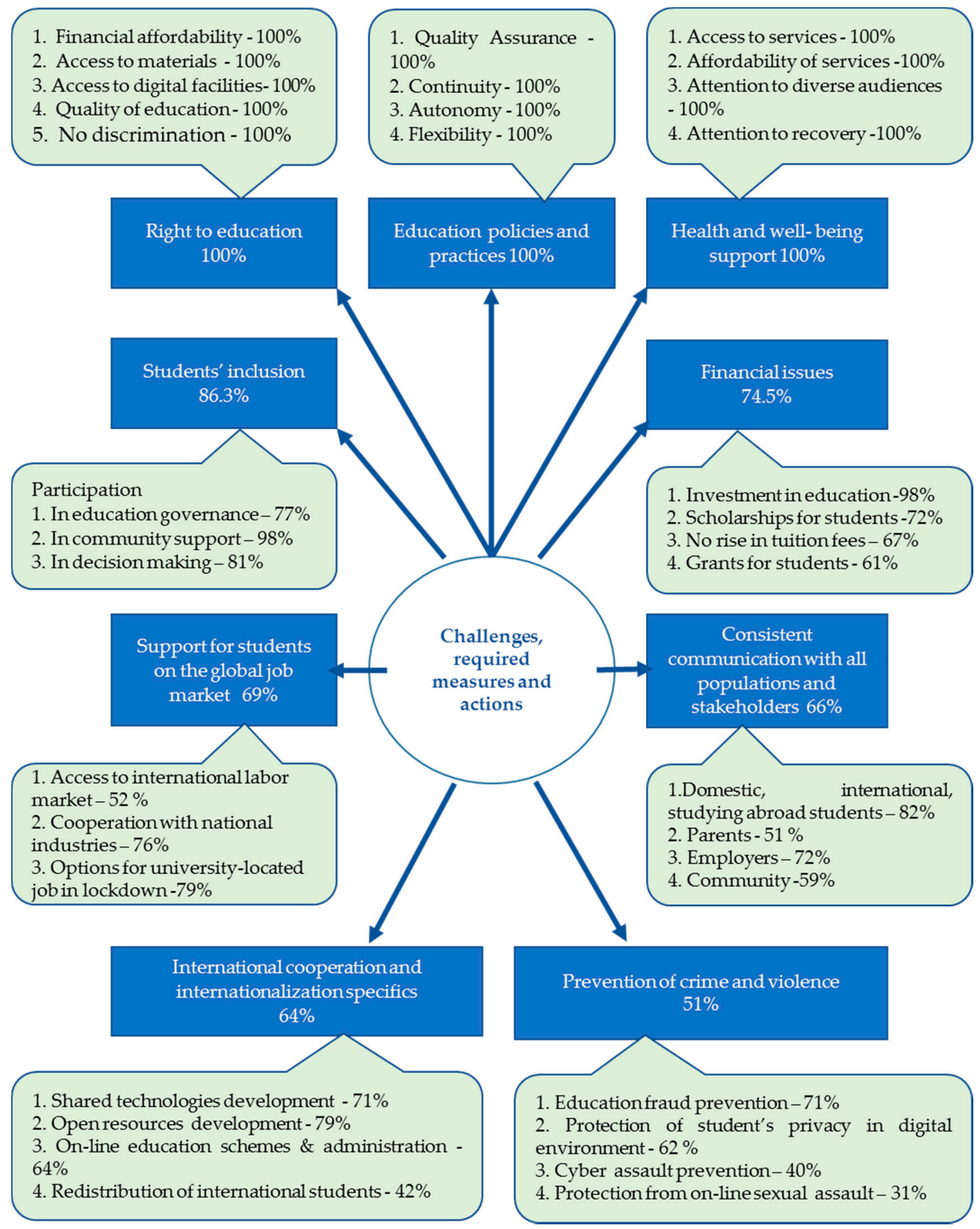

Figure 2. Concepts and their slots within the phenomenon of international organizations' discourse on higher education during COVID-19. (Author's data). 
The data reveals nine major concepts that appear in major international organizations' discourse on universities policies' and activities during COVID 19 (dark blue boxes). Only concepts whose proportion in the above data reaches at least $50 \%$ are mentioned.

The figure also marks the above concepts' constituent slots (light green boxes).

Currently, 35 slots comprise the above concepts in international organizations' communication practices. Due to organizations' comprehensive/specific field of activities, all slots which were identified in the course of investigation are mentioned, even those whose presence in the textual data does not amount to $50 \%$.

The analysis reveals that the list of these slots varies with respect to a specific organization. The most consistent list of such slots refers to the concepts of Right to education, Education policies and practices, and Health and well-being support. Communication in the other six areas reveals a lower percentage of distribution frequency of concepts' constituent slots. However, as is the case with the investigation of university discourse, the absolute percentage figures of some slots within these concepts might be $15-20 \%$ higher than the average figures for the concept itself.

As far as verbal means are concerned, Figure 2 shows that the major concepts are verbally expressed through nominative phrases organized from nouns and adjectives; prepositions and conjunctions also appear. The syntactical density often goes beyond a three-member structured phrase. This density is even higher at the level of the concept constituent slots, $12 \%$ of which are formed of five to seven language units.

\subsubsection{Topics of Particular Focus}

In line with the research tasks, we consider it relevant to provide comments with regard to the above-visualized data and highlight some topics of particular focus that international organizations cover in their communications on university education within the current pandemic.

The UN Secretary-General has launched the UN Comprehensive Response to COVID-19 [100]. These statements and this position map the challenges, specify vulnerable and marginalized youth populations, call for actions, and list necessary measures. The issues of university education are mentioned regarding several dimensions, including the vision of the right to education as one of the fundamental values, the critical need for health support and service provision, acknowledgment of such challenges as the digital divide, disrupted learning and examinations, closure of extracurricular social activities, mental health issues, and financial burden [101]. UN-affiliated agencies specify the challenges and tasks regarding sustainable support for youth.

The SDG-Education 2030 Steering Committee has drafted recommendations that focus on the continuity of learning through all stakeholders' inclusion and equity, and on exceptional support for teachers and students, underlining the critical role of government commitment to investments in education to tackle digital and economic divides. Specific attention is drawn to the issues of crisis sensitive education planning, alternative curricula, and distance learning plans to ensure remote learning quality. Particular emphasis is laid on counter-violence measures, and youth social and emotional wellbeing during the COVID 19 emergency [102].

The United Nations Office on Drugs and Crime has issued a number of documents, and the Statement on COVID-19 \& Youth seems to be of particular relevance in terms of its multidimensional nature. This document focuses on the need to support fundamental youth rights amid the pandemic from the angle of youth protection from abuse and violence. These documents also underline the need to foster youth inclusion and participation in all aspects and phases of the response to COVID 19 [103].

The United Nations Population Fund explores the dimensions within which youth has been affected during the current pandemic and underlines the importance of working with and for young people during COVID 19 in such key areas as health protection, education opportunities, social and civil security, and engagement in community communication to mitigate risks [77].

UNESCO focuses explicitly on support for the learning process across the world amid global closure of educational institutions and the need for specific attention to disadvantaged students [104]. 
The organization launched a particular portal on education during COVID 19 to ensure the continuity of education through multidimensional efforts which target national ministers, teacher community, integrate national repositories of digital learning resources and learning management systems, integrate tools for psychological support for youth, and collect student voices from all over the world. Moreover, UNESCO issued a special call to ensure and foster learning and knowledge exchange and sharing through open educational resources (OER) to support teachers and students in tackling inequalities that disadvantaged populations face [105].

The Compact for Young People in Humanitarian Action (53 international organizations, with governmental and non-governmental members, to protect women's and youth rights in emergencies) provides a comprehensive study of the situation for youth during COVID 19, exploring medical, social, educational and security challenges. This forum underlines the need for governments and communities to treat youth as systemic partners in all phases of the COVID-19 response, including work on community needs, information delivery and sharing, and protection from crime and violence [106].

The Organization for Economic Cooperation and Development [107] delivered a policy brief for education stakeholders based on a survey of youth organizations from 48 countries. The document considers COVID impact on youth, including mental health, education, and employment. The Organization further shapes recommendations for national governments to consider youth as a catalyst for resilient and inclusive societies, and to foster partnership between public governance agencies and youth associations to mitigate COVID 19 consequences and advance recovery measures.

The World Economic Forum considers stakeholders (educators, learners, policymakers and society at large) who engage in the search for solutions and decision-making process about the future of education, specifically the need for cooperation between developed and developing countries [49]. The institution draws particular attention to society's need for academically justified ethical guidelines for health care professionals' activities during the pandemic [108].

The World Bank education group provides a comprehensive response to immediate and long-term challenges, drafts recommendations in terms of university operation planning for short-term and medium-long term options, and explores specifics of the education process, including course refreshment and delivery, assessment, admissions, research, ICT quality, human factors (students, faculty, staff), administrative standards and regulations, funding, and international cooperation [109].

The international organizations that focus on particular areas of activity deliver theme-tailored messages. Thus, the World Health Organization highlights the need for non-pharmaceutical interventions to prevent and control the spread of infection in educational institutions, and the importance of attention to sexual and reproductive health [110]. The International Labor Organization outlines measures to prevent youth's exclusion from the labor market [111]. The International Association of Universities takes a specific stance on monitoring and data accumulation. The association has launched a global survey on the impact of COVID-19 on HEIs. Its aim is to explore critical challenges that institutions confront, identifying possible solutions. Besides, this organization concentrates on international, regional, and national data accumulation concerning emerging responses, policies, recommendations, university initiatives, and promising practices [112].

The regional organizations advance their policies and actions along with global trends and tailor them to the regions and agencies specific to their area of activities.

The documents of the Council of Europe (CoE) focus on legal aspects and societal dimensions of HEIs' performance during and after COVID 19. The Council underlines that universities have the duty of care to students, specifying the particular need for safeguarding students with special educational needs and for protecting vulnerable populations (i.e., refugees). The organization underlines legal responsibilities for the mental health of students, protection from cybercriminals, possible educational fraud, and outlines that on-line assessment should be secured in line with the right to privacy and without academic misconduct [113]. The CoE also considers issues of rights from such angles as academic freedom, HEI autonomy, and engagement of students, faculty, and staff. Moreover, 
CoE documents strongly emphasize that universities should be viewed as and perform their functions as "societal actors for the public good." [114]. Finally, the CoE calls for attention to multilingual resources and students' voices.

The European Students' Union (ESU) that unites 46 National Unions of Students from EU universities provides data on students' opinions revealed through surveys and consistently follows the issue of students' rights provision [115].

The EDUCAUSE (international association for higher education technology, uniting the community of IT leaders, HEIs and individuals) focuses on educational services quality during remote work and on-line learning. The organization specifies the critical difference between scheduled and emergency on-line education, underlines the importance of effective campus response to education process planning within the latter situation, expresses its commitment to free and discounted resources dissemination, and provides recommendations to keep students engaged during remote learning [116].

The QS ranking agency focuses on university social engagement and provides examples of specific universities' contribution to the community fight against the pandemic. The agency also provides varied data on graduates' job placement and tactics employed to get hired during the current pandemic. Moreover, in line with the agency policies, it focuses on advice to students on university choice for on-line education during the 2020-2021 schooling year, provides analytics with regard to keeping students engaged during on-line learning, specifies differences between on-site and on-line learning, and considers the prospects of internationalization and changes in future education [117]. Furthermore, the agency conducts ongoing surveys to help and protect prospective domestic and international students, enrich academic policies and practices, and foster education continuity across the globe during COVID 19 [118].

The Times Higher Education World University Rankings mainly discusses the quality of distance learning, aims to forecast international cooperation formats, and voices the issue of student's financial support [119].

The European Association for International Education (EAIE) emphasizes the need for consistent communication with different target audiences, including students on the campus, students studying abroad, student parents, information for the community on university societal initiatives, etc., and information for partner universities, industries and employers [120].

The above brief comments have been introduced to provide concrete examples of the themes which international organizations' discourse covers concerning higher education during COVID 19.

In general, this section's findings lead to the following discussion.

\subsubsection{Discussion}

The analysis of the above-mentioned international institutions' communication lays the grounds for comments on the conceptual-communicative profile of international and regional organizations with reference to their variables, specified in the data collection description, namely themes and genres. As far as institutional documents' variables are concerned the research has failed to draw a clear distinction among institutional communications depending on the agency's international/regional status. The institution type (multidimensional/area focused) of activity influences the comprehensive/theme-tailored scope of the topics that are covered in the documents of both international and regional organizations. As far as the genre of the textual data is concerned, position/policy papers/statements, official briefs, guidelines and recommendations tend to provide a complex multidimensional vision of youth issues and tools for youth sustainability during the COVID 19. Meanwhile, analytical papers and interviews provide a narrower, topic-specific consideration. Finally, applied modules/resources/platforms cover links to specific training tools.

The findings reveal that international institutional organizations that focus on higher education policies and development consistently address the role of modern universities in ensuring youth sustainability during COVID 19. Their messages in the form of various documents are structured into the system of concepts and their constituent slots. 
Similar to the discussion in Section 3.2, it is possible to state that international organizations' discourse on the topic under study tends to cover diverse areas of policy, tools, and activities which are verbally represented through concepts and slots considered earlier in this part of the paper. The conceptual-communicative macrostructure and its verbal representation in secondary sources' communication on the university's role in supporting youth during the COVID 19 contributes to research hypothesis statements one and two on the comprehensive role that university discourse performs in fostering youth sustainability in society in times of pandemic, and the role of language in this role representation.

The findings show that this communication ensures complex representation of worldwide university efforts to provide youth sustainability in health emergencies within the global landscape. The data, which have been visualized in figures one and two with further discussion, provides verbally explicit structures of global university and international organizations' discourse on university policies and practices during COVID 19, and shows that this discourse implements an integrated conceptual verbal phenomenon of knowledge and action. We also consider it relevant to mention that earlier research did not cover such a wide comparative scope in terms of the number of universities whose data were subject to study.

The data adds additional support for research hypothesis statement three on university discourse on youth sustainability as a verbally expressed conceptual macrostructure of knowledge and action. The findings of this part reveal that not only the discourse of primary sources (that of universities) but also the discourse of secondary sources (that of international higher education affiliated organizations) on youth issues during COVID 19 functions as a verbally expressed conceptual macrostructure of knowledge and action of the respective organization

What seems really interesting is some additional findings which were not thought about at the stage of research planning and emerged from the secondary sources data findings, which laid the ground for some comparisons and specific remarks.

The comments below are based on the comparative analysis of data in Figures 1 and 2, in Sections 3.2 and 3.3 , respectively.

The present comparative study of communication topics made it possible to identify differences between universities and international organizations concerning their communication focus on youth issues during COVID 19, though we did not envisage such a task. First, the findings reveal that universities focus on current tactics to tackle current challenges, while organizations search for strategic solutions and tools to cope with COVID 19's current and prospective challenges and negative consequences. As the visual and numerical data in Figures 1 and 2 show, particular topics across university global communication flows refer to education, campus operations, students' mental health, research role, and the university's input into society's fight against COVID 19. Meanwhile, international organizations' communication on university activities during COVID 19 lays specific emphasis on the students' right to education as a fundamental human value. This communication argues for a stronger focus on the need to tackle the digital divide and foster equity within remote learning, students' engagement in all the phases of response to the pandemic, and post COVDI 19 recovery, with a consistent call for national governments to reinforce their commitment to the mentioned tasks.

\section{Conclusions}

The empirical findings and their discussion aimed to reach a research goal that consisted in specifying trends in international institutional and university discourse in relation to youth sustainability in society amidst COVID19, from the angle of the respective discourse conceptual communicative structure representation.

To this end, the study analysed current trends in academic studies related to the research topic, and explored international universities and organizations' discourse across the world on youth issues amidst the current pandemic to identify verbally expressed concepts regarding policies and actions. 
The study has provided a comprehensive analysis of academic research on the university's role during the pandemics. The literature review shows that COVID 19 has led to increasing data on international education-related organizations and higher education institutions' policies and activities during the pandemic. This state of affairs leads to the conclusion that academia should focus on a comprehensive analysis of higher education policies and performance concerning universities' communication to foster youth sustainability in society during health emergencies and pandemics.

Further, the research findings confirm the hypothesis that university discourse can play a comprehensive role in fostering youth sustainability in society in times of pandemic. The empirical analysis and the discussion show that this role is explicitly introduced through the verbal communication of national universities and higher education organizations during COVID 19. This communication develops as a structured conceptual multidimensional discourse, which covers varied topics, and addresses them in an integrated way as interconnected and mutually dependent themes of the HEIs' communication. We introduces different actors who engage in the provision of information and services, and take part in instrument development and implementation, with the view of addressing the need for support for youth sustainability from higher education institutions, national governing bodies, and international agencies in the relevant field.

The above-mentioned comprehensive role of university communication on youth sustainability operates as a conceptual communicative macrostructure through language means which verbalizes the macrostructure of knowledge and actions. The findings show that such a macrostructure unites concepts that are similar for both university and organizations' discourse (education issues, information provision, campus operation, support for human beings, financial issues), on the one hand, and the concepts and their slots that differ. International agencies consider the university's role in enhancing youth sustainability from the angle of students' fundamental rights, focuses on societal dimensions of students' status during and after COVID 19, and urges national governments to develop policies to ensure the above rights and status. Thus, communication on students' inclusion incorporates different slots with respect to university discourse and organizational discourse, which considers this issue from a more comprehensive angle.

Moreover, the universities are still to follow international recommendations on consistent communication with different target audiences, including the domestic and international student populations, their parents, employers, and community.

Bearing in mind the above, it seems possible to shape preliminary recommendations on the expressed conceptual architecture of university communication to ensure youth sustainability through verbal discourse amidst the global pandemic.

The university should provide a comprehensive information response during health emergencies, ensuring consistent goals and result-focused communication among all the actors engaged both inside and outside the institutional space. It is critical to highlight university education policy as a complex system that in line with education quality maintenance ensures sustainable human well-being, rights, security, and students' engagement and participation in university actions addressed to society. A clear message on university and national government readiness and capacity to implement concrete actions for students' financial and career support are also critical.

Moreover, university communication to ensure youth sustainability during pandemics benefits from students' polls and concrete stories related to learning, research, volunteering, and cooperation with industry representatives. Representation of students' positive experiences during health emergency contexts contributes to downplaying misinformation, rumors, and panic in the community, and fosters an overall positive community vision and confidence in overcoming temporary challenges. The themes mentioned above, if consistently aggregated and explicitly verbalized in university communication during the pandemic outbreak, can contribute to youth sustainability at national and international levels.

The present study does not avoid some limitations related to source collection. Selection and integration of materials from other universities and international organizations, and enhancement of 
the respective pools of actors, might change the percentages of the verbal representations of concepts and their slots in the discourse under study. Therefore, further studies are expected to specify this data at both local national and international levels. Specific comparative analysis from the inside and cross-regional; perspectives bring new relevant data.

Funding: The publication has been prepared with the support of the RUDN University Program 5-100, research project number 090512-1-274.

Acknowledgments: The author expresses her deep gratitude to colleagues from the RUDN Law Institute department of Foreign Languages who kindly agreed to act as independent coders for the initial manual coding of the research data.

Conflicts of Interest: The author declares no conflict of interest.

\section{Appendix A. Primary Sources Data. Universities across the World That Were Subject to Empirical Study}

Table A1. The data source: QS World University Rankings 2021 [46].

\begin{tabular}{|c|c|c|c|c|}
\hline No. & $\begin{array}{c}\text { Region, No. of } \\
\text { Countries/Country }\end{array}$ & University & Ranking & Site \\
\hline & \multicolumn{4}{|c|}{ Africa, 2} \\
\hline 1. & South Africa & University of Cape Town & 220 & https://www.aucegypt.edu/ \\
\hline 2. & South Africa & $\begin{array}{l}\text { The University of the } \\
\text { Witwatersrand }\end{array}$ & 403 & https://www.wits.ac.za/ \\
\hline 3. & Egypt & $\begin{array}{l}\text { American University } \\
\text { of Cairo }\end{array}$ & 411 & https://www.aucegypt.edu/ \\
\hline \multirow[t]{2}{*}{4.} & Egypt & Cairo University & $561-570$ & https://cu.edu.eg/Home \\
\hline & \multicolumn{4}{|c|}{ Asia, 28} \\
\hline 5. & Singapore & $\begin{array}{l}\text { National University } \\
\text { of Singapore }\end{array}$ & 11 & http://www.nus.edu.sg/ \\
\hline 6. & Singapore & $\begin{array}{c}\text { Nanyang Technological } \\
\text { University }\end{array}$ & 13 & $\begin{array}{c}\text { https://www.ntu.edu.sg/Pages/ } \\
\text { home.aspx }\end{array}$ \\
\hline 7. & China (Mainland) & Tsinghua University & 15 & $\begin{array}{c}\text { https: } \\
\text { //www.tsinghua.edu.cn/kyzten/ }\end{array}$ \\
\hline 8. & China & Wuhan University & 246 & https://en.whu.edu.cn/ \\
\hline 9. & Hong Kong SAR & $\begin{array}{l}\text { The University of } \\
\text { Hong Kong }\end{array}$ & 22 & $\begin{array}{l}\text { https://www.hku.hk/others/ } \\
\text { covid-19/overview.html }\end{array}$ \\
\hline 10. & Hong Kong SAR & $\begin{array}{l}\text { The Hong Kong University } \\
\text { of Science and Technology }\end{array}$ & 27 & https://www.ust.hk/ \\
\hline 11. & Japan & The University of Tokyo & 24 & https://www.u-tokyo.ac.jp/en/ \\
\hline 12. & Japan & Kyoto University & 38 & https://www.kyoto-u.ac.jp/en/ \\
\hline 13. & South Korea & Seoul National University & 37 & https://en.snu.ac.kr/ \\
\hline 14. & South Korea & Korea University & 69 & http://www.korea.edu/ \\
\hline 15. & Malaysia & University of Malaya & 59 & https://www.um.edu.my/ \\
\hline 16. & Malaysia & $\begin{array}{l}\text { Universiti Putra } \\
\text { Malaysia (UPM) }\end{array}$ & 132 & https://upm.edu.my/ \\
\hline 17. & Taiwan & National Taiwan University & 66 & $\begin{array}{c}\text { https: } \\
\text { //www.ntu.edu.tw/english/ }\end{array}$ \\
\hline 18. & Taiwan & $\begin{array}{l}\text { National Tsing } \\
\text { Hua University }\end{array}$ & 168 & $\begin{array}{l}\text { https://nthu-en.web.nthu.edu. } \\
\text { tw/bin/home.php }\end{array}$ \\
\hline
\end{tabular}


Table A1. Cont.

\begin{tabular}{|c|c|c|c|c|}
\hline No. & $\begin{array}{c}\text { Region, No. of } \\
\text { Countries/Country }\end{array}$ & University & Ranking & Site \\
\hline 19. & Saudi Arabia & $\begin{array}{l}\text { King Abdulaziz } \\
\text { University (KAU) }\end{array}$ & 143 & $\begin{array}{c}\text { https://www.kau.edu.sa/home_ } \\
\text { english.aspx }\end{array}$ \\
\hline 20. & Saudi Arabia & $\begin{array}{c}\text { King Fahd University of } \\
\text { Petroleum \& } \\
\text { Minerals (KFUPM) }\end{array}$ & 186 & http://kfupm.academia.edu/ \\
\hline 21. & Kazakhstan & $\begin{array}{l}\text { Al-Farabi Kazakh } \\
\text { national University }\end{array}$ & 165 & https://www.kaznu.kz/en/ \\
\hline 22. & Kazakhstan & $\begin{array}{l}\text { L.N. Gumilyov Eurasian } \\
\text { National University (ENU) }\end{array}$ & 357 & https://www.enu.kz/en/ \\
\hline 23. & India & $\begin{array}{c}\text { Indian Institute of } \\
\text { Technology Bombay (IITB }\end{array}$ & 172 & http://www.iitb.ac.in/ \\
\hline 24. & India & Indian Institute of Science & 185 & https://www.iisc.ac.in/ \\
\hline 25. & Israel & $\begin{array}{c}\text { The Hebrew University } \\
\text { of Jerusalem }\end{array}$ & 177 & https://new.huji.ac.il/ \\
\hline 26. & Israel & Tel Aviv University & 230 & https://english.tau.ac.il/ \\
\hline 27. & $\begin{array}{l}\text { United Arab } \\
\text { Emirates }\end{array}$ & $\begin{array}{l}\text { Khalifa University of Science } \\
\text { and Technology }\end{array}$ & 211 & https://www.ku.ac.ae/ \\
\hline 28. & $\begin{array}{l}\text { United Arab } \\
\text { Emirates }\end{array}$ & $\begin{array}{c}\text { United Arab Emirates } \\
\text { University }\end{array}$ & 284 & https://www.uaeu.ac.ae/en/ \\
\hline 29. & Lebanon & $\begin{array}{l}\text { American University } \\
\text { of Beirut }\end{array}$ & 220 & https://www.aub.edu.lb/ \\
\hline 30. & Lebanon & University of Balamand & $501-510$ & $\begin{array}{l}\text { http://www.balamand.edu.lb/ } \\
\text { home/Pages/default.aspx }\end{array}$ \\
\hline 31. & Qatar & Qatar University & 245 & https://www.qu.edu.qa/ \\
\hline 32. & Indonesia & Gadjah Mada University & 254 & https://ugm.ac.id/en \\
\hline 33. & Indonesia & Universitas Indonesia & 305 & https://www.ui.ac.id/ \\
\hline 34. & Brunei & $\begin{array}{l}\text { Universiti Brunei } \\
\text { Darussalam }\end{array}$ & 254 & https://ubd.edu.bn/ \\
\hline 35. & Brunei & Universiti Teknologi Brunei & 350 & http://www.utb.edu.bn/ \\
\hline 36. & Pakistan & $\begin{array}{l}\text { National University of } \\
\text { Sciences And Technology }\end{array}$ & 355 & $\begin{array}{c}\text { https: } \\
\text { //www.nu.edu.om/default.aspx }\end{array}$ \\
\hline 37. & Pakistan & $\begin{array}{l}\text { Pakistan Institute of } \\
\text { Engineering and } \\
\text { Applied Sciences }\end{array}$ & 373 & http://www.pieas.edu.pk/ \\
\hline 38. & Macao SAR & University of Macau & 367 & https://www.um.edu.mo/ \\
\hline 39. & Macao SAR & $\begin{array}{c}\text { Macau University of Science } \\
\text { and Technology }\end{array}$ & $701-750$ & https://www.must.edu.mo/en \\
\hline 40. & Oman & Sultan Qaboos University & 375 & https://www.squ.edu.om/ \\
\hline 41. & Philippines & University of the Philippines & 396 & https://www.up.edu.ph/ \\
\hline 42. & Philippines & Ateneo de Manila University & $601-650$ & https://www.ateneo.edu/ls \\
\hline 43. & Turkey & Koç University & 465 & https://www.ku.edu.tr/en/ \\
\hline 44. & Turkey & Sabanci University & $521-530$ & https://www.sabanciuniv.edu/ \\
\hline
\end{tabular}


Table A1. Cont.

\begin{tabular}{|c|c|c|c|c|}
\hline No. & $\begin{array}{l}\text { Region, No. of } \\
\text { Countries/Country }\end{array}$ & University & Ranking & Site \\
\hline 45. & Iran & $\begin{array}{l}\text { Sharif University of } \\
\text { Technology }\end{array}$ & 409 & http://www.sharif.ir/web/en/ \\
\hline 46. & Iran & $\begin{array}{c}\text { Amirkabir University of } \\
\text { Technology }\end{array}$ & 477 & https://aut.ac.ir/en \\
\hline 47. & Jordan & University of Jordan & $601-650$ & http://ju.edu.jo/home.aspx \\
\hline 48. & Jordan & $\begin{array}{c}\text { Jordan University of Science } \\
\text { \& Technology }\end{array}$ & $651-700$ & $\begin{array}{c}\text { http://www.just.edu.jo/Pages/ } \\
\text { Default.aspx }\end{array}$ \\
\hline 49. & Bahrein & $\begin{array}{l}\text { Applied Science University } \\
\text { of Bahrain }\end{array}$ & $651-700$ & https://www.asu.edu.bh/ \\
\hline 50. & Bahrein & University of Bahrain & $801-1000$ & http://www.uob.edu.bh/en/ \\
\hline 51. & Kuwait & Kuwait University & $800-1000$ & $\begin{array}{l}\text { http://kuweb.ku.edu.kw/ku/ } \\
\text { index.htm }\end{array}$ \\
\hline 52. & Kuwait & Kuwait University & $801-1000$ & http://www.kuniv.edu/ \\
\hline 53. & Iraq & University of Baghdad & $801-1000$ & https://en.uobaghdad.edu.iq/ \\
\hline 54. & Iraq & University of Kufa & $801-1000$ & http://uokufa.edu.iq/?lang=en \\
\hline 55. & Bangladesh & $\begin{array}{l}\text { Bangladesh University of } \\
\text { Engineering and Technology }\end{array}$ & $801-1000$ & https://www.buet.ac.bd/web/ \\
\hline 56. & Bangladesh & University of Dhaka & $801-1000$ & https://www.du.ac.bd/ \\
\hline 57. & Vietnam & $\begin{array}{c}\text { Vietnam National University } \\
\text { Ho Chi Minh City }\end{array}$ & $801-1000$ & https://vnuhcm.edu.vn/ \\
\hline 58. & Vietnam & $\begin{array}{l}\text { Vietnam National } \\
\text { University, Hanoi }\end{array}$ & $801-1000$ & https://vnu.edu.vn/eng/ \\
\hline 59. & Thailand & Chulalongkorn University & 208 & https://www.chula.ac.th/en/ \\
\hline \multirow[t]{2}{*}{60.} & Thailand & Mahidol University & 252 & https://mahidol.ac.th/ \\
\hline & \multicolumn{4}{|c|}{ Europe, 29} \\
\hline 61. & United Kingdom & University of Oxford & 5 & http://www.ox.ac.uk/ \\
\hline 62. & United Kingdom & University of Cambridge & 7 & https://www.cam.ac.uk/ \\
\hline 63. & Switzerland & $\begin{array}{l}\text { Swiss Federal Institute of } \\
\text { Technology Zurich }\end{array}$ & 6 & $\begin{array}{c}\text { https: } \\
\text { //ethz.ch/services/en/news-and- } \\
\text { events/coronavirus.html }\end{array}$ \\
\hline 64. & Switzerland & $\begin{array}{c}\text { École polytechnique fédérale } \\
\text { de Lausanne }\end{array}$ & 14 & $\begin{array}{l}\text { https://www.epfl.ch/campus/ } \\
\text { security-safety/en/health/ } \\
\text { coronavirus-covid19/ }\end{array}$ \\
\hline 65. & Germany & $\begin{array}{l}\text { Technical University } \\
\text { of Munich }\end{array}$ & 50 & https://www.tum.de/en/ \\
\hline 66. & Germany & $\begin{array}{l}\text { Ludwig-Maximilians- } \\
\text { Universität München }\end{array}$ & 63 & $\begin{array}{c}\text { https://www.en.uni-muenchen. } \\
\text { de/index.html }\end{array}$ \\
\hline 67. & Netherlands & Leiden University & 46 & $\begin{array}{c}\text { https: } \\
\text { //www.universiteitleiden.nl/en }\end{array}$ \\
\hline 68. & Netherlands & University of Amsterdam & 49 & https://www.uva.nl/en?cb \\
\hline 69. & France & École Polytechnique & 61 & $\begin{array}{c}\text { https: } \\
\text { //www.polytechnique.edu/en }\end{array}$ \\
\hline
\end{tabular}


Table A1. Cont.

\begin{tabular}{|c|c|c|c|c|}
\hline No. & $\begin{array}{c}\text { Region, No. of } \\
\text { Countries/Country }\end{array}$ & University & Ranking & Site \\
\hline 70. & France & Sorbonne University & 83 & $\begin{array}{c}\text { http: } \\
\text { //www.sorbonne-universite.fr/ }\end{array}$ \\
\hline 71. & Belgium & KU Leuven & 84 & $\begin{array}{c}\text { https: } \\
\text { //www.kuleuven.be/english/ }\end{array}$ \\
\hline 72. & Belgium & Ghent University & 135 & https://www.ugent.be/en \\
\hline 73. & Sweden & Lund University & 97 & $\begin{array}{l}\text { https://www.lunduniversity.lu. } \\
\text { se/home }\end{array}$ \\
\hline 74. & Sweden & $\begin{array}{l}\text { KTH Royal Institute } \\
\text { of Technology }\end{array}$ & 98 & https://www.kth.se/en \\
\hline 75. & Ireland & $\begin{array}{l}\text { Trinity College Dublin, The } \\
\text { University of Dublin }\end{array}$ & 101 & https://www.tcd.ie/ \\
\hline 76. & Ireland & University College Dublin & 177 & https://www.ucd.ie/ \\
\hline 77. & Denmark & University of Copenhagen & 76 & https://www.ku.dk/english/ \\
\hline 78. & Denmark & $\begin{array}{c}\text { Technical University } \\
\text { of Denmark }\end{array}$ & 103 & https://www.dtu.dk/english \\
\hline 79. & Finland & University of Helsinki & 104 & https://www.helsinki.fi/en \\
\hline 80. & Finland & Aalto University & 127 & $\begin{array}{c}\text { https: } \\
\text { //www.aalto.fi/en/aaltosummer }\end{array}$ \\
\hline 81. & Norway & University of Bergen & 194 & https://www.uib.no/en \\
\hline 82. & Norway & University of Oslo & 113 & https://www.uio.no/english/ \\
\hline 83. & Italy & Politecnico di Milano & & https://www.polimi.it/en/ \\
\hline 84. & Italy & Sapienza University & 171 & https://www.uniroma1.it/en/ \\
\hline 85. & Austria & University of Vienna & 150 & https://www.univie.ac.at/en/ \\
\hline 86. & Austria & $\begin{array}{l}\text { Vienna University } \\
\text { of Technology }\end{array}$ & 191 & https://www.tuwien.at/en/ \\
\hline 87. & Spain & Universitat de Barcelona & 183 & $\begin{array}{c}\text { https://www.ub.edu/web/ub/ca/ } \\
\text { index.html }\end{array}$ \\
\hline 88. & Spain & $\begin{array}{l}\text { Universidad Autónoma } \\
\text { de Madrid }\end{array}$ & 200 & $\begin{array}{l}\text { https://www.uam.es/UAM/ } \\
\text { Home.htm?language=es\# }\end{array}$ \\
\hline 89. & Czech Republic & Charles University & 260 & https://cuni.cz/uken-1.html \\
\hline 90. & Czech Republic & $\begin{array}{l}\text { University of Chemistry and } \\
\text { Technology, Prague }\end{array}$ & 342 & https://www.vscht.cz/?jazyk=en \\
\hline 91. & Estonia & University of Tartu & 285 & https://www.ut.ee/en \\
\hline 92. & Estonia & $\begin{array}{l}\text { Tallinn University of } \\
\text { Technology (TalTech) }\end{array}$ & $651-700$ & https://old.taltech.ee/en \\
\hline 93. & Belarus & Belarusian State University & 317 & https://bsu.by/en/ \\
\hline 94. & Belarus & $\begin{array}{c}\text { Belarusian National } \\
\text { Technical University (BNTU) }\end{array}$ & $801-1000$ & http://www.bntu.by/ \\
\hline 95. & Portugal & University of Lisbon & 357 & https://www.ulisboa.pt/ \\
\hline 96. & Portugal & University of Porto & 357 & www.up.pt \\
\hline 97. & Lithuania & Vilnius University & 423 & https://www.vu.lt/ \\
\hline 98. & Lithuania & $\begin{array}{l}\text { Vilnius Gediminas } \\
\text { Technical University }\end{array}$ & $651-700$ & $\begin{array}{c}\text { https://www.vgtu.lt/index.php? } \\
\text { lang=2 }\end{array}$ \\
\hline
\end{tabular}


Table A1. Cont.

\begin{tabular}{|c|c|c|c|c|}
\hline No. & $\begin{array}{l}\text { Region, No. of } \\
\text { Countries/Country }\end{array}$ & University & Ranking & Site \\
\hline 99. & Greece & $\begin{array}{l}\text { National Technical } \\
\text { University of Athens }\end{array}$ & 477 & https://www.ntua.gr/en/ \\
\hline 100. & Greece & $\begin{array}{l}\text { Aristotle University } \\
\text { of Thessaloniki }\end{array}$ & $571-580$ & https://www.auth.gr/en \\
\hline 101. & Hungary & University of Szeged & $501-510$ & https://u-szeged.hu/english \\
\hline 102. & Hungary & University of Debrecen & $521-530$ & https://www.edu.unideb.hu/ \\
\hline 103. & Poland & University of Warsaw & 321 & https://en.uw.edu.pl/ \\
\hline 104. & Poland & Jagiellonian University & 326 & https://www.uj.edu.pl/en_GB/ \\
\hline 105. & Bulgaria & $\begin{array}{l}\text { The University of Sofia } \\
\text { (St. Kliment Ohridski) }\end{array}$ & $601-650$ & https://www.uni-sofia.bg/eng \\
\hline 106. & Ukraine & $\begin{array}{l}\text { V. N. Karazin Kharkiv } \\
\text { National University }\end{array}$ & 477 & $\begin{array}{c}\text { https: } \\
\text { //www.univer.kharkov.ua/en }\end{array}$ \\
\hline 107. & Ukraine & $\begin{array}{l}\text { Taras Shevchenko National } \\
\text { University of Kyiv }\end{array}$ & $601-650$ & http://www.univ.kiev.ua/en/ \\
\hline 108. & Slovenia & University of Ljubljana & $601-650$ & https://www.uni-lj.si/eng/ \\
\hline 109. & Slovenia & University of Maribor & $801-1000$ & $\begin{array}{c}\text { https://www.um.si/en/Pages/ } \\
\text { default.aspx }\end{array}$ \\
\hline 110. & Slovakia & $\begin{array}{l}\text { Pavol Jozef Šafárik } \\
\text { University in Košice }\end{array}$ & $651-700$ & https://www.upjs.sk/ \\
\hline 111. & Slovakia & $\begin{array}{l}\text { Comenius University } \\
\text { in Bratislava }\end{array}$ & $701-750$ & $\begin{array}{l}\text { https://medizinstudieren- } \\
\text { slowakei.de/ }\end{array}$ \\
\hline 112. & Latvia & Riga Technical University & $701-750$ & https://www.rtu.lv/en \\
\hline 113. & Latvia & Riga Stradins University & $801-1000$ & https://www.rsu.lv/en \\
\hline 114. & Romania & Babes-Bolyai University & $801-1000$ & https://www.ubbcluj.ro/en/ \\
\hline 115. & Romania & University of Bucharest & $801-1000$ & https://unibuc.ro/?lang=en \\
\hline 116. & Malta & University of Malta & $801-1000$ & https://www.um.edu.mt/ \\
\hline 117. & Croatia & University of Rijeka & $801-1000$ & https://uniri.hr/en/home/ \\
\hline 118. & Croatia & University of Zagreb & $801-1000$ & $\begin{array}{c}\text { http: } \\
\text { //www.unizg.hr/homepage/ }\end{array}$ \\
\hline & \multicolumn{4}{|c|}{ Latin America, 12} \\
\hline 119. & Argentine & $\begin{array}{l}\text { Universidad de } \\
\text { Buenos Aires }\end{array}$ & 66 & http://www.uba.ar/ \\
\hline 120. & Argentine & $\begin{array}{l}\text { Pontificia Universidad } \\
\text { Católica Argentina }\end{array}$ & 326 & http://uca.edu.ar/es \\
\hline 121. & Mexico & $\begin{array}{l}\text { Universidad Nacional } \\
\text { Autónoma de México }\end{array}$ & 100 & https://www.unam.mx/ \\
\hline 122. & Mexico & Tecnológico de Monterrey & 155 & https://tec.mx/es \\
\hline 123. & Brazil & Universidade de São Paulo & 115 & https://www5.usp.br/ \\
\hline 124. & Brazil & $\begin{array}{l}\text { Universidade Estadual de } \\
\text { Campinas (Unicamp) }\end{array}$ & 233 & $\begin{array}{c}\text { https: } \\
\text { //www.unicamp.br/unicamp/ }\end{array}$ \\
\hline 125. & Chile & Universidad de Chile & 180 & https://www.uchile.cl/ \\
\hline
\end{tabular}


Table A1. Cont.

\begin{tabular}{|c|c|c|c|c|}
\hline No. & $\begin{array}{c}\text { Region, No. of } \\
\text { Countries/Country }\end{array}$ & University & Ranking & Site \\
\hline 126. & Chile & $\begin{array}{l}\text { Pontificia-universidad- } \\
\text { católica-de-Chile }\end{array}$ & 121 & https://www.uc.cl/ \\
\hline 127. & Colombia & Universidad de los Andes & 227 & https://uniandes.edu.co/ \\
\hline 128. & Colombia & $\begin{array}{l}\text { Universidad Nacional de } \\
\text { Colombia }\end{array}$ & 259 & https://unal.edu.co/ \\
\hline 129. & Peru & $\begin{array}{l}\text { Pontificia Universidad } \\
\text { Católica del Perú }\end{array}$ & 432 & https://www.pucp.edu.pe/ \\
\hline 130. & Peru & $\begin{array}{c}\text { Universidad Peruana } \\
\text { Cayetano Heredia (UPCH) }\end{array}$ & $701-750$ & $\begin{array}{l}\text { https://www.cayetano.edu.pe/ } \\
\text { cayetano/es/ }\end{array}$ \\
\hline 131. & Uruguay & Universidad ORT Uruguay & 462 & https://www.ort.edu.uy/ \\
\hline 132. & Uruguay & $\begin{array}{l}\text { Universidad de } \\
\text { Montevideo (UM) }\end{array}$ & 492 & https://www.um.edu.uy/ \\
\hline 133. & Cuba & Universidad de La Habana & 498 & http://www.uh.cu/ \\
\hline 134. & Cuba & $\begin{array}{c}\text { Universidad Central “Marta } \\
\text { Abreu” de Las Villas }\end{array}$ & $531-540$ & https://www.uclv.edu.cu/ \\
\hline 135. & Costa Rica & Universidad de Costa Rica & $571-580$ & https://www.ucr.ac.cr/ \\
\hline 136. & Costa Rica & $\begin{array}{c}\text { Tecnológico de Costa } \\
\text { Rica-TEC }\end{array}$ & $801-1000$ & https://www.tec.ac.cr/ \\
\hline 137. & Ecuador & $\begin{array}{l}\text { Universidad San Francisco } \\
\text { de Quito (USFQ) }\end{array}$ & $751-800$ & $\begin{array}{l}\text { http://www.usfq.edu.ec/ } \\
\text { Paginas/Inicio.aspx }\end{array}$ \\
\hline 138. & Ecuador & Escuela Politécnica Nacional & $801-1000$ & https://www.epn.edu.ec/ \\
\hline 139. & Venezuela & $\begin{array}{l}\text { Universidad Central } \\
\text { de Venezuela }\end{array}$ & $751-800$ & http://www.ucv.ve/ \\
\hline 140. & Venezuela & $\begin{array}{c}\text { Universidad Católica } \\
\text { Andres Bello }\end{array}$ & $801-1000$ & https://www.ucab.edu.ve/ \\
\hline 141. & Panama & $\begin{array}{c}\text { Universidad Tecnológica } \\
\text { de Panamá }\end{array}$ & $801-1000$ & http://www.utp.ac.pa/ \\
\hline \multicolumn{5}{|c|}{ North America, 2} \\
\hline 142. & United States & Stanford university & 2 & https://www.stanford.edu/ \\
\hline 143. & United States & Harvard University & 3 & https://www.harvard.edu/ \\
\hline 144. & Canada & University of Toronto & 25 & https://www.utoronto.ca/ \\
\hline 145. & Canada & Mc Gill University & 31 & https://www.mcgill.ca/ \\
\hline \multicolumn{5}{|c|}{ Oceania, 2} \\
\hline 146. & Australia & The University of Sydney & 40 & https://www.sydney.edu.au \\
\hline 147. & Australia & The University of Melbourne & 41 & https://www.unimelb.edu.au/ \\
\hline 148. & New Zealand & University of Auckland & 81 & $\begin{array}{c}\text { https: } \\
\text { //www.auckland.ac.nz/en.html }\end{array}$ \\
\hline 149. & New Zealand & University of Otago & 184 & https://www.otago.ac.nz/ \\
\hline
\end{tabular}




\section{Appendix B. Primary Sources Data. Russian Universities That Were Subject to Empirical Study}

Table A2. The data sources: Project 5-100 [121], QS World University Rankings 2021 [46].

\begin{tabular}{|c|c|c|c|}
\hline No. & University & $\begin{array}{l}\text { Ranking System } \\
\text { and Position }\end{array}$ & University Web-Site \\
\hline & \multicolumn{3}{|c|}{ Two founding universities of Russia } \\
\hline 1. & Lomonosov Moscow State University & QS Ranking \#74 & https://www.msu.ru/en/ \\
\hline \multirow[t]{2}{*}{2.} & Saint Petersburg State University & QS Ranking \#225 & https://english.spbu.ru/ \\
\hline & \multicolumn{3}{|c|}{ Russian academic excellence project 5-100 member universities } \\
\hline 3. & $\begin{array}{c}\text { Immanuel Kant } \\
\text { Baltic Federal } \\
\text { University }\end{array}$ & $\begin{array}{c}\text { EECA University } \\
\text { Rankings } \\
\# 188\end{array}$ & https://eng.kantiana.ru/ \\
\hline 4. & Far Eastern Federal University & QS Ranking \#493 & https://www.dvfu.ru/en/ \\
\hline 5. & Higher School of Economics & QS Ranking \#298 & https://www.hse.ru/en/ \\
\hline 6. & ITMO University & QS Ranking \#360 & https://en.itmo.ru/en/ \\
\hline 7. & Kazan Federal university & QS Ranking \#370 & https://kpfu.ru/eng \\
\hline 8. & $\begin{array}{l}\text { Lobachevsky State University of } \\
\text { Nizhni Novgorod }\end{array}$ & QS Ranking \#601-650 & http://eng.unn.ru/ \\
\hline 9. & $\begin{array}{l}\text { Moscow Institute of Physics } \\
\text { and Technology }\end{array}$ & QS Ranking \#281 & https://mipt.ru/english/ \\
\hline 10. & $\begin{array}{c}\text { National University of Science and } \\
\text { Technology (MISIS) }\end{array}$ & QS Ranking \#428 & https://en.misis.ru/ \\
\hline 11. & $\begin{array}{c}\text { National Research Nuclear } \\
\text { University Mephi }\end{array}$ & QS Ranking \#314 & https://eng.mephi.ru/ \\
\hline 12. & Novosibirsk State University & QS Ranking \#228 & https://english.nsu.ru/ \\
\hline 13. & $\begin{array}{l}\text { Peter the Great St. Petersburg } \\
\text { Polytechnic University }\end{array}$ & QS Ranking \#401 & www.spbstu.ru \\
\hline 14. & RUDN University & QS Ranking \#326 & http://eng.rudn.ru/ \\
\hline 15. & $\begin{array}{l}\text { Saint Petersburg Electrotechnical } \\
\text { University "LETI" }\end{array}$ & QS Ranking \#701-750 & https://etu.ru/ \\
\hline 16. & Samara State University & QS Ranking \#591-600 & https://ssau.ru/ \\
\hline 17. & South Ural State University & QS Ranking \#801-1000 & https://www.susu.ru/en \\
\hline 18. & $\begin{array}{c}\text { Sechenov First Moscow State } \\
\text { Medical University }\end{array}$ & $\begin{array}{c}\text { EECA University } \\
\text { Rankings } \\
\# 154\end{array}$ & https://www.sechenov.ru/eng/ \\
\hline 19. & Siberian Federal University & QS Ranking \#801-1000 & www.sfu-kras.ru/ \\
\hline 20. & Tomsk State University & QS Ranking \#250 & http://en.tsu.ru/ \\
\hline 21. & Tomsk Polytechnic University & & www.tpu.ru \\
\hline 22. & University of Tyumen & $\begin{array}{c}\text { EECA University } \\
\text { Rankings } \\
\text { \#211-220 } \\
\text { BRICS Rankings } \\
\# 301-350\end{array}$ & https://www.utmn.ru/en/ \\
\hline 23. & Ural Federal State University & QS Ranking \#331 & www.urfu.ru \\
\hline
\end{tabular}




\section{Appendix C. Secondary Sources Data}

Table A3. International and Regional Institutions Web-Platforms Whose Textual Data Were Subject to Empirical Study.

\begin{tabular}{|c|c|c|}
\hline & International Organizations & Web-Platform \\
\hline 1. & UNO. COVID-19 Response & https://www.un.org/en/coronavirus \\
\hline 2. & UNESCO. COVID-19 RESPONSE. & https://en.unesco.org/covid19 \\
\hline 3. & $\begin{array}{l}\text { United Nations Office on Drugs and Crime. } \\
\text { COVID-19 Response }\end{array}$ & https://www.unodc.org/unodc/en/covid-19.html \\
\hline 4. & $\begin{array}{l}\text { United Nations Population Fund. } \\
\text { COVID-19 pandemic }\end{array}$ & https://www.unfpa.org/covid19 \\
\hline 5. & The SDG-Education 2030 Steering Committee & https://sdg4education2030.org/ \\
\hline 6. & Compact for Young Peoples & $\begin{array}{c}\text { https: } \\
\text { //www.youthcompact.org/the-compact-response }\end{array}$ \\
\hline 7. & $\begin{array}{l}\text { COVID-19 response toolkit } \\
\text { (UNESCO-Global Education Coalition, 2020) }\end{array}$ & $\begin{array}{l}\text { https: } \\
\text { //www.sdg4education2030.org/covid-19-response- } \\
\text { toolkit-unesco-global-education-coalition-2020 }\end{array}$ \\
\hline 8. & International Labor organization & $\begin{array}{c}\text { https://www.ilo.org/ } \\
\text { https://www.ilo.org/Search5/search.do?sitelang= } \\
\text { en\&locale=en_EN\&consumercode=ILOHQ__ } \\
\text { STELLENT_PUBLIC\&searchWhat=COVID19\& } \\
\text { searchLanguage=en }\end{array}$ \\
\hline 9. & $\begin{array}{l}\text { International Association of Universities. } \\
\text { Covid-19: Higher Education challenges } \\
\text { and responses }\end{array}$ & $\begin{array}{l}\text { https://www.iau-aiu.net/Covid-19-Higher- } \\
\text { Education-challenges-and-responses }\end{array}$ \\
\hline 10. & $\begin{array}{c}\text { Organization for Economic Cooperation and } \\
\text { Development [Youth and COVID } 19 . \\
\text { Response, Recovery] }\end{array}$ & https://www.oecd.org/coronavirus/en/ \\
\hline 11. & $\begin{array}{l}\text { World Bank. World Bank Group and } \\
\text { COVID-19 (coronavirus) }\end{array}$ & $\begin{array}{l}\text { https://www.worldbank.org/en/who-we-are/news/ } \\
\text { coronavirus-covid19?intcid=wbw_xpl_banner_ } \\
\text { en_ext_Covid19 }\end{array}$ \\
\hline 12. & $\begin{array}{l}\text { World Economic Forum. COVID } \\
\text { Action Platform. }\end{array}$ & https://www.weforum.org/covid-action-platform \\
\hline 13. & $\begin{array}{l}\text { World Health Organization. Coronavirus } \\
\text { disease (COVID-19) pandemic. }\end{array}$ & $\begin{array}{c}\text { https://www.who.int/emergencies/diseases/novel- } \\
\text { coronavirus-2019 }\end{array}$ \\
\hline \multicolumn{3}{|c|}{ Regional organizations } \\
\hline 14. & $\begin{array}{l}\text { Council of Europe. COVID-19: Council of } \\
\text { Europe actions. }\end{array}$ & https://www.coe.int/en/web/portal/covid-19 \\
\hline 15. & $\begin{array}{l}\text { European Association for International } \\
\text { Education (EAIE). COVID-19 resources }\end{array}$ & https://www.eaie.org/our-resources/covid-19.html \\
\hline 16. & $\begin{array}{c}\text { European Students' Union (ESU). COVID-19 } \\
\text { Position Paper-A multidimensional crisis } \\
\text { that affects us all }\end{array}$ & $\begin{array}{c}\text { https://www.esu-online.org/wp-content/uploads/ } \\
\text { 2020/04/\%E2\%80\%9CCOVID-19-Position-Paper- } \\
\text { A-multidimensional-crisis-that-affects-us-all. } \\
\text { \%E2\%80\%9D-1.pdf }\end{array}$ \\
\hline 17. & EDUCAUSE. COVID 19 (2020). & $\begin{array}{l}\text { https://library.educause.edu/topics/information- } \\
\text { technology-management-and-leadership/covid-19 }\end{array}$ \\
\hline 18. & $\begin{array}{l}\text { OECD Policy Responses to Coronavirus } \\
\text { (COVID-19). Youth and COVID-19: Response, } \\
\text { Recovery and Resilience. }\end{array}$ & $\begin{array}{l}\text { http://www.oecd.org/coronavirus/policy- } \\
\text { responses/youth-and-covid-19-response-recovery- } \\
\text { and-resilience-c40e61c6/ }\end{array}$ \\
\hline \multicolumn{3}{|c|}{ International ranking agencies } \\
\hline 19. & $\begin{array}{l}\text { International Student Survey (2020). QS-EU. } \\
\text { London, UK: QS. }\end{array}$ & $\begin{array}{l}\text { https://www.qs.com/portfolio-items/international- } \\
\text { student-survey-2020-report-volume-4-the- } \\
\text { decade-ahead/ }\end{array}$ \\
\hline 20. & $\begin{array}{l}\text { QS World University Rankings. COVID-19: } \\
\text { News and Information. }\end{array}$ & $\begin{array}{c}\text { https: } \\
\text { //www.topuniversities.com/coronavirus-covid-19 }\end{array}$ \\
\hline 21. & $\begin{array}{c}\text { Times Higher Education World University } \\
\text { Ranking. Coronavirus }\end{array}$ & $\begin{array}{l}\text { https://www.timeshighereducation.com/policy/ } \\
\text { coronavirus }\end{array}$ \\
\hline
\end{tabular}




\section{References}

1. United Nations Organization. Transforming Our World: The 2030 Agenda for Sustainable Development. Resolution adopted by the General Assembly on 25 September 2015. Available online: https: //sustainabledevelopment.un.org/post2015/transformingourworld (accessed on 30 May 2020).

2. Yueqin, H.; Weimin, D.; Zhaorui, L. Psychosocial Aspects in Three Universities during SARS Epidemic in Beijing. Chin. Ment. Health J. 2003, 17, 521-523.

3. Hays, J.N. Epidemics and Pandemics: Their Impacts on Human History; Abc-clio: Santa Barbara, CA, USA, 2005.

4. Davis, M.; Lohm, D. Pandemics, Publics, and Narrative; Oxford University Press: Oxford, UK, 2020.

5. Hart, C. Multimodal Discourse Analysis. In Researching Discourse; Routledge: London, UK, 2020; pp. $143-179$.

6. Fidler, D.P. Germs, governance, and global public health in the wake of SARS. J. Clin. Investig. 2004, 113, 799-804. [CrossRef] [PubMed]

7. Main, A.; Zhou, Q.; Ma, Y.; Luecken, L.J.; Liu, X. Relations of SARS-related stressors and coping to Chinese college students' psychological adjustment during the 2003 Beijing SARS epidemic. J. Couns. Psychol. 2011, 58, 410-423. [CrossRef] [PubMed]

8. Wong, T.W.; Gao, Y.; Tam, W.W.S. Anxiety among university students during the SARS epidemic in Hong Kong. Stress and Health. J. Int. Soc. Investig. Stress 2007, 23, 31-35. [CrossRef]

9. Yang, H.; Bin, P.; He, A.J. Opinions from the epicenter: An online survey of university students in Wuhan amidst the COVID-19 outbreak1. J. Chin. Gov. 2020, 5, 234-248. [CrossRef]

10. Bergeron, S.L.; Sanchez, A.L. Media effects on students during SARS outbreak. Emerg. Infect. Dis. 2005, 11, 732-734. [CrossRef]

11. Iuliano, A.D.; Reed, C.; Guh, A.; Desai, M.; Dee, D.L.; Kutty, P.; Mitchell, T. Notes from the field: Outbreak of 2009 pandemic influenza A (H1N1) virus at a large public university in Delaware, April-May 2009. Clin. Infect. Dis. 2009, 49, 1811-1820. [CrossRef]

12. Pons, V.G.; Canter, J.; Dolin, R. Influenza A/USSR/77 (H1N1) on a university campus. Am. J. Epidemiol. 1980, 111, 23-30. [CrossRef]

13. Park, J.H.; Cheong, H.K.; Son, D.Y.; Kim, S.U.; Ha, C.M. Perceptions and behaviors related to hand hygiene for the prevention of H1N1 influenza transmission among Korean university students during the peak pandemic period. BMC Infect. Dis. 2010, 10, 222. [CrossRef]

14. Suresh, P.S.; Thejaswini, V.; Rajan, T. Factors associated with 2009 pandemic influenza A (H1N1) vaccination acceptance among university students from India during the post-pandemic phase. BMC Infect. Dis. 2011, 11, 205. [CrossRef]

15. Zhou, X.; Wu, Y.T.; Wu, Z.H. Mental status of college students and its interventional mechanism during outbreak of A/H1N1 influenza. Health Res. 2009, 5. Available online: http://en.cnki.com.cn/Article_en/ CJFDTotal-HZYG200905007.htm (accessed on 30 May 2020).

16. Akan, H.; Gurol, Y.; Izbirak, G.; Ozdatlı, S.; Yilmaz, G.; Vitrinel, A.; Hayran, O. Knowledge and attitudes of university students toward pandemic influenza: A cross-sectional study from Turkey. BMC Public Health 2010, 10, 413. [CrossRef] [PubMed]

17. Van, D.; McLaws, M.L.; Crimmins, J.; MacIntyre, C.R.; Seale, H. University life and pandemic influenza: Attitudes and intended behaviour of staff and students towards pandemic (H1N1) 2009. BMC Public Health 2010, 10, 130. [CrossRef] [PubMed]

18. Katz, R.; May, L.; Sanza, M.; Johnston, L.; Petinaux, B. H1N1 preventive health behaviors in a university setting. J. Am. Coll. Health 2012, 60, 46-56. [CrossRef]

19. Zottarelli, L.K.; Sunil, T.S.; Flott, P.; Karbhari, S. College student adoption of non-pharmaceutical interventions during the 2009 H1N1 influenza pandemic: A study of two Texas universities in Fall 2009. Prev. Med. 2012, 55, 497-499. [CrossRef]

20. Ganzermiller, A.L. Staying Connected During Crisis: A Look into How Universities Communicate and Notify Their Campus of Emergencies. Master's Thesis, Towson University, Towson, MD, USA, 2013.

21. Anoko, J.N.; Barry, B.R.; Boiro, H.; Diallo, B.; Diallo, A.B.; Belizaire, M.R.; Fall, I.S. Community engagement for successful COVID-19 pandemic response: 10 lessons from Ebola outbreak responses in Africa. BMJ Glob. Health 2020, 4 (Suppl. 7), e003121. [CrossRef] 
22. Abad-Segura, E.; González-Zamar, M.D.; Antonio Luque-de la Rosa, A.; Morales Cevallos, M.B. Sustainability of Educational Technologies: An Approach to Augmented Reality Research. Sustainability 2020, 12, 4091. [CrossRef]

23. Zamora-Polo, F.; Sánchez-Martín, J.; Corrales-Serrano, M.; Espejo-Antúnez, L. What do university students know about sustainable development goals? A realistic approach to the reception of this UN program amongst the youth population. Sustainability 2019, 11, 3533. [CrossRef]

24. Santiago, A.M.; Smith, R.J. Community practice, social action, and the politics of pandemics. J. Community Pract. 2020, 28, 89-99. [CrossRef]

25. Sehnem, S.; Martignago, G.; Pereira, S.C.F.; Jabbour, C.J.C. Sustainable Management at a University in Light of Tensions of Sustainability Theory. Rev. Adm. Contemp. 2019, 23, 182-206. [CrossRef]

26. Amaral, A.R.; Rodrigues, E.; Gaspar, A.R.; Gomes, Á. A review of empirical data of sustainability initiatives in university campus operations. J. Clean. Prod. 2020, 250, 119558. [CrossRef]

27. Al-Rahmi, W.M.; Alzahrani, A.I.; Yahaya, N.; Alalwan, N.; Kamin, Y.B. Digital Communication: Information and Communication Technology (ICT) Usage for Education Sustainability. Sustainability 2020, 12, 5052. [CrossRef]

28. Abad-Segura, E.; González-Zamar, M.D.; Infante-Moro, J.C.; Ruipérez García, G. Sustainable Management of Digital Transformation in Higher Education: Global Research Trends. Sustainability 2020, 12, 2107. [CrossRef]

29. Wang, C.; Cheng, Z.; Yue, X.G.; McAleer, M. Risk management of COVID-19 by universities in China. J. Risk Financ. Manag. 2020, 13, 36. [CrossRef]

30. Wodak, R.; Meyer, M. Critical discourse analysis: History, agenda, theory and methodology. In Methods of Critical Discourse Analysis, 3rd ed.; Ruth, W., Michael, M., Eds.; Sage: London, UK, 2015; pp. 1-33.

31. Halliday, M.A.K. Language as Social Semiotic: The Social Interpretation of Language and Meaning; Hodder Arnold: London, UK, 1978.

32. Van Dijk, T.A. Macrostructures: An Interdisciplinary Study of Global Structures in Discourse, Interaction, and Cognition; Routledge: London, UK, 2019.

33. Krossa, A.S. Borders, Others, Selves: Concepts of a Discourse. In Analysing Society in a Global Context; Palgrave Macmillan: Cham, Switzerland, 2020; pp. 49-80.

34. Teubert, W. Meaning, Discourse and Society; Cambridge University Press: Cambridge, UK, 2010.

35. Minsky, M. A framework for representing knowledge. In Readings in Cognitive Science. A Perspective from Psychology and Artificial Intelligence; Morgan Kaufmann Publishers: San Francisco, CA, USA, 1988; pp. 156-189. [CrossRef]

36. Buttigieg, P.L.; Pafilis, E.; Lewis, S.E.; Schildhauer, M.P.; Walls, R.L.; Mungall, C.J. The environment ontology in 2016: Bridging domains with increased scope, semantic density, and interoperation. J. Biomed. Semant. 2016, 7, 57. [CrossRef]

37. Lähdesmäki, T.; Koistinen, A.K.; Ylönen, S.C. Analysing Intercultural Dialogue through Conceptual Densities. In Intercultural Dialogue in the European Education Policies; Palgrave Macmillan: Cham, Switzerland, 2020; pp. 61-79.

38. Tarozzi, M. What Is Grounded Theory? Bloomsbury Publishing: London, UK, 2020.

39. Foucault, M. The Archaeology of Knowledge; Routledge: London, UK, 2002.

40. Alpi, K.M.; Evans, J.J. Distinguishing case study as a research method from case reports as a publication type. J. Med Libr. Assoc. 2019, 107, 1. [CrossRef]

41. Ridder, H.G. Case Study Research: Approaches, Methods, Contribution to Theory; Rainer Hampp Verlag: Munich, Germany, 2019.

42. Upton, T.A.; Cohen, M.A. An approach to corpus-based discourse analysis: The move analysis as example. Discourse Stud. 2009, 11, 585-605. [CrossRef]

43. Villares, R. The role of language policy documents in the internationalisation of multilingual higher education: An exploratory corpus-based study. Languages 2019, 4, 56. [CrossRef]

44. Jaspal, R. Content analysis, thematic analysis and discourse analysis. In Research Methods in Psychology, 5th ed.; Breakwell, G.M., Wright, D.B., Barnett, J., Eds.; Sage: London, UK, 2020; pp. 285-312.

45. Amaral, I.; Santos, S. Social Networks and Institutional Communication: The Case of Portuguese Universities. Prism. Soc. 2020, 28, 20-43.

46. QS Top Universities. Available online: https://www.topuniversities.com/university-rankings/worlduniversity-rankings/2021 (accessed on 30 May 2020). 
47. Krippendorff, K. Content Analysis: An Introduction to Its Methodology; Sage Publications: Thousand Oaks, CA, USA, 2018.

48. Malec, M. Essential Statistics for Social Research; Routledge: London, UK, 2018.

49. Johnson, N.; Veletsianos, G.; Seaman, J. US Faculty and Administrators' Experiences and Approaches in the Early Weeks of the COVID-19 Pandemic. Online Learn. 2020, 24, 6-21. [CrossRef]

50. Pan, S.L.; Zhang, S. From fighting COVID-19 pandemic to tackling sustainable development goals: An opportunity for responsible information systems research. Int. J. Inf. Manag. 2020, in press. [CrossRef] [PubMed]

51. Regehr, C.; Goel, V. Managing COVID-19 in a Large Urban Research-Intensive University. J. Loss Trauma 2020, 1-17. [CrossRef]

52. Mossa-Basha, M.; Medverd, J.; Linnau, K.; Lynch, J.B.; Wener, M.H.; Kicska, G.; Sahani, D. Policies and guidelines for COVID-19 preparedness: Experiences from the University of Washington. Radiology 2020, 201326. [CrossRef] [PubMed]

53. Salman, M.; Mustafa, Z.U.; Asif, N.; Zaidi, H.A.; Hussain, K.; Shehzadi, N.; Saleem, Z. Knowledge, attitude and preventive practices related to COVID-19: A cross-sectional study in two Pakistani university populations. Drugs Ther. Perspect. 2020, 36, 319-325. [CrossRef]

54. Basir, S.N.M.; Bakar, M.Z.A.; Ismail, F.; Hassan, J. Conceptualizing on Structure Functionalism and Its Applications on Patriotism Study during Covid-19 Pandemic in Malaysia. South Asian J. Soc. Stud. Econ. 2020, 6, 1-7. [CrossRef]

55. Abbott, A.; Askelson, N.; Scherer, A.M.; Afifi, R.A. Critical Reflections on COVID-19 Communication Efforts Targeting Adolescents and Young Adults. J. Adolesc. Health 2020. [CrossRef]

56. Efuribe, C.; Barre-Hemingway, M.; Vaghefi, E.; Suleiman, A.B. Coping with the COVID-19 crisis: A call for youth engagement and the inclusion of young people in matters that affect their lives. J. Adolesc. Health 2020. [CrossRef]

57. Starikova, E. Abstracts for the International Youth Conference' Regeneration: Youth Leadership in Rebuilding a Post COVID-19 Sustainable World with SDGs'. In Proceedings of the Moscow State Institute of International Relations (MGIMO), Moscow, Russia, 30 May 2020.

58. Marciano, J.E.; Peralta, L.M.; Lee, J.S.; Rosemurgy, H.; Holloway, L.; Bass, J. Centering community: Enacting culturally responsive-sustaining YPAR during COVID-19. J. Multicult. Educ. 2020. [CrossRef]

59. David, L. We are at war: The rise of expert knowledge. Ir. J. Sociol. 2020. [CrossRef]

60. Blustein, D.L.; Duffy, R.; Ferreira, J.A.; Cohen-Scali, V.; Cinamon, R.G.; Allan, B.A. Unemployment in the time of COVID-19: A research agenda. J. Vocat. Behav. 2020, 119, 103436. [CrossRef]

61. Abidah, A.; Hidaayatullaah, H.N.; Simamora, R.M.; Fehabutar, D.; Mutakinati, L. The Impact of Covid-19 to Indonesian Education and Its Relation to the Philosophy of "Merdeka Belajar". Stud. Philos. Sci. Educ. 2020, 1, 38-49. [CrossRef]

62. Peters, M.A.; Wang, H.; Ogunniran, M.O.; Huang, Y.; Green, B.; Chunga, J.O.; Khomera, S.W. China's internationalized higher education during Covid-19: Collective student autoethnography. Postdigital Sci. Educ. 2020, 1. [CrossRef]

63. Crawford, J.; Butler-Henderson, K.; Rudolph, J.; Glowatz, M. COVID-19: 20 Countries' Higher Education Intra-Period Digital Pedagogy Responses. J. Appl. Teach. Learn. 2020, 3. [CrossRef]

64. Bao, W. COVID-19 and online teaching in higher education: A case study of Peking University. Hum. Behav. Emerg. Technol. 2020, 2, 113-115. [CrossRef] [PubMed]

65. Basilaia, G.; Dgebuadze, M.; Kantaria, M.; Chokhonelidze, G. Replacing the Classic Learning Form at Universities as an Immediate Response to the COVID-19 Virus Infection in Georgia. Int. J. Res. Appl. Sci. Eng. Technol. 2020, 8, 101-108. [CrossRef]

66. Owusu-Fordjour, C.; Koomson, C.K.; Hanson, D. The impact of Covid-19 on learning-the perspective of the Ghanaian student. Eur. J. Educ. Stud. 2020, 7, 88-100. [CrossRef]

67. Duong, V.; Pham, P.; Yang, T.; Wang, Y.; Luo, J. The ivory tower lost: How college students respond differently than the general public to the covid-19 pandemic. arXiv 2020, arXiv:2004.09968.

68. Dufty, N. Disaster Education, Communication and Engagement; John Wiley \& Sons: Hoboken, NJ, USA, 2020.

69. Liang, L.; Ren, H.; Cao, R.; Hu, Y.; Qin, Z.; Li, C.; Mei, S. The effect of COVID-19 on youth mental health. Psychiatr. Q. 2020, 1-12. [CrossRef] 
70. Odriozola-González, P.; Planchuelo-Gómez, Á.; Irurtia, M.J.; de Luis-García, R. Psychological effects of the COVID-19 outbreak and lockdown among students and workers of a Spanish university. Psychiatry Res. 2020, 113108. [CrossRef]

71. Sahu, P. Closure of universities due to Coronavirus Disease 2019 (COVID-19): Impact on education and mental health of students and academic staff. Cureus 2020, 12, e7541. [CrossRef]

72. Seçer, İ.; Ulaş, S. An Investigation of the Effect of COVID-19 on OCD in Youth in the Context of Emotional Reactivity, Experiential Avoidance, Depression and Anxiety. Int. J. Ment. Health Addict. 2020, 1-14. [CrossRef] [PubMed]

73. Margaritis, I.; Houdart, S.; el Ouadrhiri, Y.; Bigard, X.; Vuillemin, A.; Duché, P. How to deal with COVID-19 epidemic-related lockdown physical inactivity and sedentary increase in youth? Adaptation of Anses' benchmarks. Arch. Public Health 2020, 78, 1-6. [CrossRef] [PubMed]

74. Drummond, M.; Elliott, S.; Drummond, C.; Prichard, I. Youth sport and COVID-19: A potential generation lost. Emerald Open Res. 2020, 2, 27. [CrossRef]

75. Gagnon, J.C. The Solitary Confinement of Incarcerated American Youth during COVID-19. Psychiatry Res. 2020, 291, 113219. [CrossRef] [PubMed]

76. Wang, G.; Zhang, Y.; Zhao, J.; Zhang, J.; Jiang, F. Mitigate the effects of home confinement on children during the COVID-19 outbreak. Lancet 2020, 395, 945-947. [CrossRef]

77. United Nations Population Fund. COVID-19: Working with and for Young People. Available online: https://www.unfpa.org/resources/covid-19-working-and-young-people (accessed on 30 May 2020).

78. Teo, S.S.; Griffiths, G. Child protection in the time of COVID-19. J. Paediatr. Child Health 2020. [CrossRef]

79. A I-Youbi, A.O.; Al-Hayani, A.; Bardesi, H.J.; Basheri, M.; Lytras, M.D.; Aljohani, N.R. The King Abdulaziz University (KAU) pandemic framework: A methodological approach to leverage social media for the sustainable management of higher education in crisis. Sustainability 2020, 12, 4367. [CrossRef]

80. Stone, L. (Ed.) The University in Society, Volume I: Oxford and Cambridge from the 14th to the Early 19th Century; Princeton University Press: Princeton, NJ, USA, 2019.

81. Stone, L. (Ed.) The University in Society, Volume II: Europe, Scotland, and the United States from the 16th to the 20th Century; Princeton University Press: Princeton, NJ, USA, 2019.

82. Albareda-Tiana, S.; Ruíz-Morale, J.; Azcárate, P.; Valderrama-Hernández, R.; Múñoz, J.M. The EDINSOST project: Implementing the sustainable development goals at university level. In Universities as Living Labs for Sustainable Development; Springer: Cham, Switzerland, 2020; pp. 193-210.

83. Sasson, I. Building a sustainable university-community partnership: Case study in science education. Stud. High. Educ. 2019, 44, 2318-2332. [CrossRef]

84. Mayr, A. Language and Power: An Introduction to Institutional Discourse; A\&C Black: London, UK, 2008.

85. Bonvillain, N. Language, Culture, and Communication: The Meaning of Messages; Rowman \& Littlefield: Lanham, MD, USA, 2019.

86. Matras, Y. Language Contact; Cambridge University Press: Cambridge, UK, 2020.

87. YouTube Channel. Russian Federation Ministry of Science and Education. Russian Federation Ministry of Science and Education Video Conferences on Education during COVID 19 (Period of March-June 2020). Available online: https://www.youtube.com/channel/UCtKQPCIdo9bDaSAw9y8A69Q (accessed on 30 May 2020).

88. MSU Faculty of Global Processes. Information on Situation Task Force as a University/Faculty-Wide Provisional Division. Available online: http://fgp.msu.ru/11652-2/ (accessed on 30 May 2020).

89. Kremlin Portal. Education under COVID-19: Meeting of the President of the Russian Federation with the Head of the Ministry of Education and Science of Russia, on 22 May 2020. Available online: http: //www.kremlin.ru/events/president/news/63376 (accessed on 30 May 2020).

90. Ministry of Science and Higher Education of the Russian Federation. Russian Federation Ministry of Science and Education Order No 566 (Dated 9 April 2020). On the Organization of Support for Students Who Study at Educational Institutions on Educational Programs of Higher Education and Receive State Social Scholarships, in the Context of Preventing the Spread of New Coronavirus Infection (COVID-19) in the Russian Federation. Available online: https://www.minobrnauki.gov.ru/common/upload/library/2020/04/566.pdf (accessed on 30 May 2020). 
91. Peter the Great St. Petersburg Polytechnic University. Rector of SPbPU Ordered to Provide One-Time Financial Assistance to All University Students. Available online: https://www.spbstu.ru/media/news/ studencheskaya_zhizn/material-assistance-students-coronavirus-epidemic/ (accessed on 30 May 2020).

92. The Parliament Newspaper. Russian Federation Minister of Science and Education Told about the Program of Support for Students' Job Placement (Dated 4 April 2020). Available online: https://www.pnp.ru/social/ falkov-rasskazal-o-programme-trudoustroystva-studentov-v-period-pandemii.html (accessed on 30 May 2020).

93. Tomsk State University. Tomsk State University Launched the University Labor Exchange for Students Who Lost Their Part-Time Income Due to COVID 19 (6 April 2020). Available online: http://www.tsu.ru/news/tgusozdal-birzhu-dlya-studentov-poteryavshikh-pod/ (accessed on 30 May 2020).

94. RUDN Students about Life on Campus for the Program “Andrei Malakhov. Live”. Российский университет дружбы народов. Available online: https:/www.facebook.com/watch/?v=617821195465321 (accessed on 30 May 2020).

95. Interfax Education. More than 70\% of Russian Students are Satisfied with the Technical Equipment of Their Online Education during the Coronavirus. Available online: https://academia.interfax.ru/ru/news/articles/ 4717/ (accessed on 30 May 2020).

96. Far Eastern Federal University. FEFU Students and Teachers Are Invited to Take an Online Learning Survey. Available online: https://www.dvfu.ru/news/fefu-news/students_and_teachers_of_the_university_ are_invited_to_participate_in_a_survey_about_online_learning/(accessed on 30 May 2020).

97. Lobachevsky State University of Nizhni Novgorod. Survey for Students on the Transition to Distance Learning. Available online: http://www.unn.ru/site/about/news/opros-dlya-studentov-o-perekhode-nadistantsionnoe-obuchenie (accessed on 30 May 2020).

98. UrFU Information on COVID 19 in Several Language. Available online: https://urfu.ru/es/ (accessed on 30 May 2020).

99. Zwaan, R.A. Situation models, mental simulations, and abstract concepts in discourse comprehension. Psychon. Bull. Rev. 2016, 23, 1028-1034. [CrossRef]

100. United Nations. UN COVID 19 Response. Available online: https://www.un.org/en/coronavirus/UNresponse (accessed on 30 May 2020).

101. United Nations Organization. Protecting and Mobilizing Youth in COVID-19 Responses. Available online: https://www.un.org/development/desa/youth/news/2020/05/covid-19/ (accessed on 30 May 2020).

102. SDG-Education 2030 Steering Committee Recommendations for COVID-19 Education Response. Available online: https://sdg4education2030.org/sites/default/files/2020-04/SDG-Education\%202030\%20SC\% 20recommendations\%20-\%20COVID-19\%20education\%20response.pdf (accessed on 30 May 2020).

103. United Nations Office on Drugs and Crime. Statement on COVID-19 \& Youth (dated 27 April 2020). Available online: https://www.unodc.org/documents/Advocacy-Section/IAYND_Statement_on_COVID-19_ and_Youth_FINAL.pdf (accessed on 30 May 2020).

104. UNESCO. Universities Tackle the Impact of COVID-19 on Disadvantaged Students (2020). Available online: https://en.unesco.org/news/universities-tackle-impact-covid-19-disadvantaged-students (accessed on 30 May 2020).

105. UNESCO. Open Education Resources Platform. Available online: https://en.unesco.org/covid19/ educationresponse/solutions (accessed on 30 May 2020).

106. Compact for Young People in Humanitarian Action-New Guidance on Working with and for Young-People during the COVID-19 Pandemic. The Youth Compact. Available online: https://www.youthcompact.org/thecompact-response (accessed on 30 May 2020).

107. Organization for Economic Cooperation and Development. Youth and COVID 19. Response, Recovery and Resilience. Available online: http://www.oecd.org/coronavirus/policy-responses/youth-and-covid-19response-recovery-and-resilience-c40e61c6/ (accessed on 30 May 2020).

108. World Economic Forum. Education and Skills COVID-19. Available online: https//www.weforum.org/ agenda/2020/08/how-edtech-will-transform-learning-in-the-covid-19-era/ (accessed on 30 May 2020).

109. The COVID-19 Crisis Response: Supporting Tertiary Education for Continuity, Adaptation, and Innovation World Bank Group. Education. Available online: http://pubdocs.worldbank.org/en/621991586463915490/WBTertiary-Ed-and-Covid-19-Crisis-for-public-use-April-9.pdf (accessed on 30 May 2020). 
110. UNESCO. COVID Impact on Education. Available online: https://en.unesco.org/covid19/educationresponse/ (accessed on 30 May 2020).

111. International Labour Organisation. Preventing Exclusion from the Labour Market: Tackling the COVID-19 Youth Employment Crisis. Available online: https://www.ilo.org/emppolicy/pubs/WCMS_746031/lang--en/ index.htm (accessed on 30 May 2020).

112. International Association of Universities. Covid-19: Higher Education Challenges and Responses. Available online: https://www.iau-aiu.net/Covid-19-Higher-Education-challenges-and-responses (accessed on 30 May 2020).

113. Council of Europe. Young People and Government Representatives Working Together to Mitigate COVID-19 Effects. Available online: https://www.coe.int/en/web/youth/covid-19 (accessed on 30 May 2020).

114. Council of Europe. Universities must Help Shape the Post COVID 19 World. Available online: https://www. coe.int/en/web/higher-education-and-research/-/universities-must-help-shape-the-post-covid-19-world (accessed on 30 May 2020).

115. European Students' Union. COVID-19 Position Paper-A multidimensional Crisis That Affects Us All. Available online: https://www.esu-online.org/wp-content/uploads/2020/04/\%E2\%80\%9CCOVID-19-PositionPaper-A-multidimensional-crisis-that-affects-us-all.\%E2\%80\%9D-1.pdf (accessed on 30 May 2020).

116. EDUCAUSE. EDUCAUSE COVID 19. Available online: https://ibrary.educause.edu/topics/informationtechnology-management-and-leadership/covid-19 (accessed on 30 May 2020).

117. Top Universities. COVID-19: News and Information. Available online: https://www.topuniversities.com/ coronavirus-covid-19 (accessed on 30 May 2020).

118. QS Insight: Reports. Quacquarelli Symonds. Available online: https://www.qs.com/covid-19-resourcesupdates/ (accessed on 30 May 2020).

119. THE World University Rankings. Coronavirus. Available online: https://www.timeshighereducation.com/ policy/coronavirus (accessed on 30 May 2020).

120. European Association for International Education. Coping with COVID-19: International Higher Education in Europe. Available online: https://www.eaie.org/our-resources/library/publication/Research-and-trends/ Coping-with-COVID-19--International-higher-education-in-Europe.html (accessed on 30 May 2020).

121. Project 5-100. Available online: https://5top100.ru/en/ (accessed on 30 May 2020).

(C) 2020 by the author. Licensee MDPI, Basel, Switzerland. This article is an open access article distributed under the terms and conditions of the Creative Commons Attribution (CC BY) license (http://creativecommons.org/licenses/by/4.0/). 